\title{
Commercializing university research in transition economies: technology transfer offices or direct industrial funding?
}

Article

Accepted Version

Creative Commons: Attribution-Noncommercial-No Derivative Works 4.0

Belitski, M., Aginskaja, A. and Marozau, R. (2019)

Commercializing university research in transition economies: technology transfer offices or direct industrial funding?

Research Policy, 48 (3). pp. 601-615. ISSN 0048-7333 doi: https://doi.org/10.1016/j.respol.2018.10.011 Available at https://centaur.reading.ac.uk/80575/

It is advisable to refer to the publisher's version if you intend to cite from the work. See Guidance on citing.

To link to this article DOI: http://dx.doi.org/10.1016/j.respol.2018.10.011

Publisher: Elsevier

All outputs in CentAUR are protected by Intellectual Property Rights law, including copyright law. Copyright and IPR is retained by the creators or other copyright holders. Terms and conditions for use of this material are defined in the End User Agreement.

www.reading.ac.uk/centaur 
Central Archive at the University of Reading

Reading's research outputs online 


\title{
Commercializing University Research in Transition Economies: Technology Transfer Offices or Direct Industrial Funding?
}

\begin{abstract}
There is a paucity of knowledge on research commercialization by university scientists worldwide. The objective of this paper is to identify the role that Technology Transfer Offices (TTOs) and direct Industrial Funding play in university research commercialization in transition economies of Azerbaijan, Belarus and Kazakhstan during 2015-2017. We do this by developing a novel database and a multi-level model which explains how individual attributes, organizational and ecosystem characteristics explain the extent of knowledge commercialization .

We apply the generalized Heckman approach to account for two selection biases, reducing the sample from 2,602 to 272 scientists, and further use a mixed-method approach to analyse 27 faceto-face interviews with researchers and TTO managers. The results demonstrate that research commercialization is not associated with the existence and awareness of TTO or the establishment of commercialization contracts via TTO, but the direct industrial funding of university research. Taken together the findings have clear implications for scholars, scientific entrepreneurs, TTOs and investors who aim to exploit university knowledge in transition economies.
\end{abstract}

\section{KEYWORDS}

Technology Transfer Offices, Industry funding, knowledge spillover, knowledge transfer, academic entrepreneurship, transition

\section{Introduction}

The role of contemporary universities has become multifaceted (Etzkowitz et al. 2000; Bishop et al., 2011; Perkmann et al. 2011a, 2013; Hvide and Jones, 2016) and encompasses teaching, research and entrepreneurship function (Audretsch, 2014). Universities implement farreaching changes to become more entrepreneurial (Mets, 2009; Siegel and Wright, 2015;

Cunningham and Link, 2015; Díez-Vial and Montoro-Sánchez, 2016) and technology transfer processes are being set up to promote research commercialisation (Lockett et al., 2003; Lockett and Wright, 2005; Phan and Siegel, 2006). Research commercialization requires building a strong external partnership with ecosystem stakeholders (Bogler, 1994; Bozeman and Gaughan, 2007; Bekkers and Freitas, 2008; Miller et al. 2014; Acs et al. 2017) such as entrepreneurs, universities, local and national government, private industry.

The financial returns from and mechanisms of university knowledge transfers have remained under researched and have triggered an interest across entrepreneurship scholars and policy makers 
in developed countries (Chapple et al., 2005; Wright et al. 2006; Kenney and Patton, 2009; Kalar and Antoncic, 2015; Abreu et al. 2016) and developing countries (Sedaitis, 2000; Varblane et al. 2007a, 2007b; Bajmócy et al. 2010; Marozau and Guerrero, 2016; Guerrero and Urbano, 2017). Responding to public research commercialization opportunities, universities have explored a number of models of university knowledge transfer with entrepreneurship centres, university incubators, science parks and TTOs performing a role of a conduit (Link et al. 2007; Siegel et al. 2003, 2007; Wright et al. 2008; Kenney and Patton, 2009; Muscio, 2010; O’Kane et al. 2015; Kolympiris and Klein, 2017).

Although substantial research in the field of academic entrepreneurship has been conducted in developed economies (Siegel et al. 2003, 2004; Powers and Mcdougall, 2005; Phan and Siegel, 2006; Perkmann et al. 2011a, 2011b; Ankrah and al-Tabbaa, 2015; Mosey et al. 2017), the field remains fragmented and incomplete in transition economies (Varblane et al. 2007a, 2007b; Marozau and Guerrero, 2016). Empirical evidence of how knowledge spills at universities and reaches industry is very limited in these countries (Radosevic, 1998; Kwiek, 2012; Leydesdorff et al. 2015; Huyghe et al. 2016).

There is a lack of relevant data on the mechanisms of knowledge transfer from universities, regulation, incentives, culture and the external investment in research (Tchalakov et al. 2010). While the TTOs remains a new phenomenon, direct industrial funding has demonstrated its strength as a conduit of university knowledge transfer (Boardman and Ponomariov, 2009; Czarnitzki et al. 2015, 2016). Direct industrial funding is defined as industry's direct financial support for the development of technology by a university scientist(s). To the best of our knowledge, no research to date has established and empirically tested the role that university TTO and direct industrial funding play in research commercialization by scientists in transition economies (Grimaldi et al. 2011; Bradley et al. 2013; Guerrero et al. 2016; Theodoraki and Messeghem, 2017). This study bridges the gap.

Adopting the TTO perspective of the knowledge spillover theory of entrepreneurship 
(KSTE) in organizations (Acs et al. 2013; Shu et al. 2014) and the stakeholder perspective to entrepreneurship ecosystem framework (Grimaldi et al. 2011; Miller et al. 2014), we respond to the call in academic entrepreneurship literature (Aldridge and Audretsch, 2011; Perkmann et al. 2011a, 2011b, 2013; Siegal and Wright, 2015; Mosey et al. 2017) and entrepreneurship ecosystem literature (Acs et al. 2014; 2017) - to investigate research commercialization in transition economies, while accounting for a broad range of individual, organizational and ecosystem level characteristics (Link and Siegel, 2005; Boardman and Ponomariov, 2009; Kenney and Patton, 2009; Stam and Spigel, 2017). These characteristics include professional level attributes such as amount of local and international publications, position, workload, research sponsorship, TTO collaboration and awareness as well as organizational level characteristics (university ownership, availability of TTO, contract relationship with TTO) and ecosystem level characteristics related to scientist's research funding by government, private industry in a home country and abroad, affiliated university, foreign universities or institutions, non-for-profits, other public organizations). We start with the premise that there is a substantial variation in traditional and alternative models of university technology transfer (Siegel et al,. 2003, 2004; Kenney and Goe, 2004; Bradley et al. 2013), that governs scientist's decision-making on research commercialization (Kenney and Patton, 2009).

We use the unique primary data on 2,602 scientists collected by online survey in Belarus, Kazakhstan and Azerbaijan between November 2015 and August 2017. Having applied for two potential selection bias corrections: one for commercialization income disclosure and another for commercialization activity, our final model consists of 272 scientists. Belarus, Kazakhstan and Azerbaijan are representative transition economies with substantial research commercialization activity, with residents and non-residents currently hold 2503 (Belarus), 3218 (Kazakhstan) and 345 (Azerbaijan) World Intellectual Property Organization (WIPO) active patents (WIPO, 2018). We validate our empirical findings with a mixed-method analysis of 27 face-to-face interviews with researchers and TTO managers during April 2016 - September 2017. A mixed 
method approach was demanded, because we had a compelling reason to suspect that measuring and analysing the commercialization of university research by relying solely upon data collected by the TTOs (Aldridge and Audretsch, 2011) or universities (Caldera and Debande, 2010) may lead to a systematic underestimation of knowledge transfers.

Taken together our results suggest that TTO activity neither impede nor facilitate research commercialization by scientists, while direct industrial funding stands as an efficient conduit for research commercialization. Although most scientists expressed their support to the "Professor Privilege" -type system (Hvide and Jones, 2016), vesting ownership with the inventor (Kenney and Patton, 2009) may take years in the troubled transition context.

The next section introduces the theoretical framework and formulates the research hypotheses. Section 3 describes the data and methodology. Section 4 describes results. Section 5 discusses the paper's main findings and section 6 concludes.

\section{Background Literature}

\subsection{Knowledge transfers from universities to industry}

Over the years, several scholars have studied the process of transferring knowledge from universities (Gulbrandsen and Smeby, 2005; Grimaldi et al. 2011; Aldridge and Audretsch, 2011; Freitas et al. 2013; Díez-Vial and Montoro-Sánchez, 2016; Guerrero et al. 2016) which could be either intentional (knowledge transfer) or unintentional (knowledge spillover) (Audretsch et al. 2005; Audretsch and Keilbach, 2009). Prior research identified stakeholders that facilitate knowledge adoption and commercialization such as TTO, and the channels of commercialization, such as licencing technology (Bradley et al. 2013) and university spin-offs, that represent one of the most visible forms of knowledge transfer (Di Gregorio and Shane 2003; Lockett et al. 2003). Even though the knowledge transfer is often formalized (Siegel et al. 2003, 2004), the role of scientists in the knowledge transfer is not obvious (van Looy et al. 2004; Grimaldi et al. 2011). The term scientist is used as a descriptor for a university researcher. 
As in any entrepreneurial process, there are individual, organizational and contextual filters

118 that limit the knowledge transfer and prevent a complete transformation of knowledge into

119 economically viable products (Acs et al. 2013; Guerrero and Urbano, 2014; Shu et al. 2014). The

120 economics of entrepreneurship allows us to understand the main environmental factors that

121 influence the organizational filters (Guerrero and Urbano 2012, 2014; Miller et al. 2014), while the

122 KSTE explains the role of regional, organizational and individual characteristics in the knowledge

123 transfer (Kenney and Goe, 2004; Guerrro and Urbano 2014; Urbano and Guerrero, 2013; Shu et al.

124 2014). The "Bayh-Dole" Act and "Professor Privilege" system are often used as an example to

125 explain how individual, organizational and contextual filters could be effectively leveraged so that

126 knowledge transfer takes place between scientists and industry (Perkmann and Walsh, 2010;

127 Grimaldi et al. 2011; Aldridge and Audretsch 2011; Hvide, and Jones, 2016).

Unlike European economies (Wright et al. 2007, 2008), transition and developing

economies have never experienced neither "Bayh-Dole"-type regulation in the US (So et al. 2008;

Korosteleva and Belitski, 2017) nor "Professor Privilege -type system in Germany (Czarnitzki et al. 2015) and Norway (Hvide and Jones, 2016). Studies seeking to explain knowledge transfer from a university using the KSTE at the organizational and individual levels (Audretsch et al. 2005; Acs et

133 al. 2013; Guerrero and Urbano, 2014) have identified a number of internal (organisational) and

134 external (environmental) factors that either facilitate or impede the process of knowledge transfer.

135 One important factor is the establishment of a university TTO (Siegel and Wessner, 2012; Siegel

136 and Wright, 2015) and engagement with private industry (Clarysse and Moray 2004; Boardman and

137 Ponomariov, 2009; Clarysse et al. 2011; Díez-Vial and Montoro-Sánchez, 2016). The differences

138 between the traditional KSTE and a TTO perspective of the KSTE are described in Table 1 using

139 Shu's et al. (2014) classification criteria.

Table 1. A TTO perspective of the knowledge spillover theory of entrepreneurship

\begin{tabular}{|l|l|l|}
\hline Empirical existence & Traditional KSTE framework & KSTE in TTOs \\
\hline $\begin{array}{l}\text { National and regional levels (Acs et al. 2013, } \\
\text { 2014; Audretsch, 2014) }\end{array}$ & $\begin{array}{l}\text { Organizational level (Shu et al. 2014) with } \\
\text { an individual perspective of the KSTE } \\
\text { (Guerrero and Urbano, 2014) and }\end{array}$ \\
\hline
\end{tabular}




\begin{tabular}{|c|c|c|}
\hline & & $\begin{array}{l}\text { university perspective (Audretsch et al. } \\
\text { 2005; Audretsch and Keilbach, 2009) }\end{array}$ \\
\hline Theoretical bases & $\begin{array}{l}\text { Endogenous growth theory (Arrow, 1962) } \\
\text { KSTE in various contexts (e.g. university, } \\
\text { region, city) (Audretsch et al. 2005; Shu et } \\
\text { al. 2014) }\end{array}$ & $\begin{array}{l}\text { Entrepreneurship ecosystem theory (Stam, } \\
\text { 2015; Stam and Spigel, 2017), the } \\
\text { evolution of technology transfer } \\
\text { competencies at universities (Clarysse et } \\
\text { al. 2011; Ankrah and Al-Tabbaa, 2015) }\end{array}$ \\
\hline Contextual factors & $\begin{array}{l}\text { Regional level and entrepreneurship } \\
\text { environment (Kenney and Patton, 2005; } \\
\text { Agarwal et al. 2010) }\end{array}$ & $\begin{array}{l}\text { University entrepreneurial orientation } \\
\text { (Aldridge and Audretsch, 2011; Grimaldi } \\
\text { et al. 2011; Kalar and Antoncic, 2015) }\end{array}$ \\
\hline Knowledge filters & $\begin{array}{l}\text { Formal and informal institutions (risk } \\
\text { aversion of stakeholders, legal restrictions, } \\
\text { bureaucracy, labour market rigidities, taxes, } \\
\text { and lack of cognition and trust) (Agarwal et } \\
\text { al. 2010; Shu et al. 2014) }\end{array}$ & $\begin{array}{l}\text { Knowledge management and } \\
\text { commercialization (Audretsch, 2014). }\end{array}$ \\
\hline Knowledge spillovers & $\begin{array}{l}\text { Investment in knowledge, collaboration and } \\
\text { labour mobility (Acs et al 2013), creativity } \\
\text { (Audretsch and Belitski, 2013) }\end{array}$ & $\begin{array}{l}\text { Knowledge transfer and knowledge } \\
\text { spillover from the university to ecosystem } \\
\text { stakeholders (Grimaldi et al. 2011; } \\
\text { Guerrero and Urbano, 2014) }\end{array}$ \\
\hline $\begin{array}{l}\text { Relationship } \\
\text { between knowledge filters } \\
\text { and spillovers }\end{array}$ & $\begin{array}{l}\text { Indirect (Agarwal et al. 2010; Acs et al. } \\
\text { 2013) }\end{array}$ & Indirect (Acs et al. 2013) \\
\hline Consequences & $\begin{array}{l}\text { Entrepreneurial performance is measured at } \\
\text { regional or national levels (new business } \\
\text { start-ups, survival, quality of } \\
\text { entrepreneurship, high growth) }\end{array}$ & $\begin{array}{l}\text { Commercialization income of a scientist } \\
\text { and/or TTO }\end{array}$ \\
\hline
\end{tabular}

Source: Authors with criteria adopted from Shu et al (2014)

\subsection{Determinants of knowledge commercialization: a multilevel model}

The process of research commercialization is a multi-level and involves interactions between an individual researcher, a university and the external environment (Powers and McDougall 2005;

148 Guerrero and Urbano, 2014; Theodoraki and Messeghem, 2017). Freitas et al. (2013) distinguish

149 two modes of interaction: the institutional mode, which involves interactions between the university

150 and ecosystem stakeholders (industry, government, non-for-profit, angel investors); and the

151 personal contractual mode, which is a formal and informal collaboration between ecosystem

152 stakeholders and scientists, carried out with or without the direct involvement of a university.

153 Building on Freitas et al. (2013), Grimaldi et al. (2011), Perkmann et al. (2011a, 2013) and

154 Guerrero and Urbano (2014), Figure 1 illustrates a three-level model of university research

155 commercialization, which connects scientist's behaviour, organizational structures and ecosystem

156 environment factors (Aldridge and Audretsch, 2011). 
158

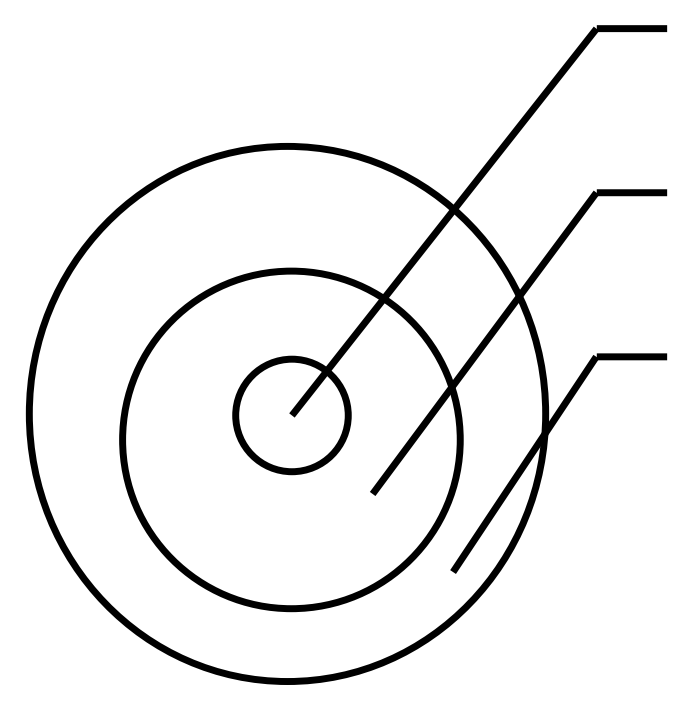

Scientist entrepreneur decision -making and returns to commercialization (individual level)

University characteristics (TTO, technoparks, incubators), form of ownership (private, public, mixed) (organizational level)

Country formal and informal institutions, socioeconomic conditions and collaboration with entrepreneurial ecosystem stakeholdres (venture capital, private capital, public institutions, government) (system level).

Figure 1: Multi-level model of university research commercialization

The first (system/ecosystem) level of analysis focuses on the business and socioeconomic environment (Cooke et al., 1997; Stam, 2015; Audretsch and Belitski, 2017; MIT REAP, 2017).

National innovation activity, intellectual property (IP) and other institutional reforms (So et al.

2008), the role that policy makers can have in the university's commercialization activities (Florida and Kenney 1988) and the variety of entrepreneurship ecosystem stakeholders either support or impede research commercialization. According to existing literature on entrepreneurial ecosystems the presence of stakeholders facilitates entrepreneurial decision-making (Audretsch et al. 2005; Audretsch, 2014; Ankrah and Al-Tabbaa, 2015; Stam, 2015). When the entrepreneurial ecosystem context is conducive, scientists at universities will leverage available resources and information via engagement with ecosystem stakeholders to transfer and commercialize new knowledge (Perkmann and Walsh, 2010; Acs et al., 2017). This creates strong links between scientists and university TTOs, where the invention is initially disclosed as well as between university and industry, where the invention is adopted and commercialized. Once the invention has been disclosed, TTOs will decide whether or not to further commercialize it (acquire a patent, discuss commercials potential 
the prospective users, market technology, negotiate licencing agreements, licence technology) (Cooke et al., 1997; Siegel et al. 2004; Link and Siegel, 2005; Shu et al., 2014). For this reason, the theoretical framework used to study the interaction between a university and ecosystem stakeholders, builds on the TTO's perspective of the KSTE.

In contrast, an entrepreneurship ecosystem with weak institutional context works in the opposite fashion (Wright et al., 2006, 2008). Below are the few examples. First, instead of disclosing the information to TTOs, which will later market the technology to organizations and entrepreneurs, providing revenues to the university, scientists will choose directly interact with private companies bypassing the university administration and TTOs (Thursby and Thursby, 2004). To access the extent of the alternative modes of research commercialization it is necessary to study the individual level data, measuring the relationship between scientist's behaviour and individual commercialization income. Second, as the invention has never been disclosed, the TTO will not be able to market it to entrepreneurs and organizations, will not negotiate the licence and not sign the licencing agreement. For this reason, the theoretical framework used to study the interaction between a scientist and ecosystem stakeholders, builds on the stakeholders' perspective to entrepreneurship ecosystem framework (Grimaldi et al. 2011; Miller et al. 2014; Stam, 2015; MIT REAP, 2017; Acs et al. 2014, 2017; Audretsch and Belitski, 2017). The literature distinguishes between five potential groups of ecosystem stakeholders who may be involved in university research commercialization: entrepreneurs, risk capital providers, universities (TTOs), policy makers (government) and large corporations (private industry).

The second (organizational) level of analysis focuses on universities and their ownership, the administrative structures within them that support research commercialization (TTOs, academic departments, techno parks, incubators) (Carayol and Matt, 2004; Audretsch et al., 2005; Dasgupta and David, 1994; Guerrero et al., 2016). The university level explains the efforts by university TTOs to seek out new commercialization opportunities (Siegel et al., 2004, 2007; Clarysse et al., 2004, 2011), facilitate early evaluation of IP rights strategies, exploit infrastructure, stimulate 
specific venture initiatives and spin-offs (Kenney and Patton, 2005; Wright et al., 2007, 2009), and attract public and private funds (Degroof and Roberts, 2004; Wright et al. 2009; Mosey et al. 2017).

Several successful initiatives to support academic and student entrepreneurship have been

Stanford University Network, and others (Mustar et al., 2006; Chapple et al., 2005; Grimaldi et al.

2011). However, universities in many developing and transition countries do not have the same organizational flexibility or high-quality academic entrepreneurship ecosystems.

While the TTO was not an invention of national regulation in transition economies, as with

their counterparts in developed countries, the TTOs activities include, but not limited to collecting information on their external partners, registering contracts and protecting the IP (Lockett et al., 2003; Markman et al., 2005b; Lockett and Wright, 2005; Siegel et al., 2007; Perkmann et al., 2013; Huyghe et al., 2016). To illustrate wider TTO's functions in transition economies, we use an example of TTO in a leading regional university in Belarus which includes collection, analysis, creation of a data banks, dissemination and collection of information on research activities of the university and enterprise needs; participation in conferences, seminars, exhibitions; registration and signing contacts between university and researchers as well as industry; implementation of scientific research, exchange of scientific and technical information with national and foreign institutions, provision of information to other technology transfer centres; facilitation of scientific research and development; training scholars and researchers (GSTU, 2017). Two important TTo functions are missing. First, evaluating the invention and deciding whether or not to pursue acquiring a patent (copyright, trademark). This is usually done in negotiation with scientists and potential user of the invention. Second, investing in invention as well as involvement of scientists in the further stages of extensive adaptation of invention (Bradley et al. 2013). 
invention (van Looy et al. 2004; Jain et al. 2009; Guerrero and Urbano, 2014) and facilitating knowledge spillovers (Audretsch, 2014). Scientist's decision-making and a choice of the knowledge transfer model is affected by the ecosystem and university levels, and in particular by their perception of the efficiency of the organizational mechanisms (TTOs, incubators, techno parks and so on) (Kenney and Patton, 2009; Kolympiris and Klein, 2017). The theoretical framework has its roots in the field of Entrepreneurial Theories (ET), investigating the individual attributes and incentives (Kenney and Patton, 2005; Jain, et al. 2009; Parkmann et al. 2013; Guerrero and Urbano, 2014) which affect how research is commercialized (Thursby and Thursby, 2004).

\subsection{Conceptual model and research hypotheses.}

The process of research commercialization is multi-dimensional (Figure 1). Firstly, individual characteristics matter (e.g. position, field of science (basic, applied), proportion of time dedicated to research versus teaching, administration or commercialization, age of scientists, number of research publications) (Aldridge and Audretsch, 2011). Secondly, university environment, institutions (e.g. TTO, Centers for commercialization) and university ownership matter (Algieri et al. 2013). Thirdly, the ecosystem stakeholders influence the entrepreneurial efforts and decision-making on research commercialization (Kenney and Patton 2009).

A traditional university knowledge transfer model (Siegel et al. 2003) includes the active role of organizational mechanisms in facilitating research commercialization (Bradley et al. 2013). The academic entrepreneurship concludes that organizational mechanisms are not homogeneous across universities (Mowery et al. 2004). Availability of financial resources and practice-oriented staff, a strong business reputation and a number of successfully-completed contracts since the TTO was established (Markman et al., 2005a), are important if TTOs are to market invention and to generate new university start-ups and spin-offs (Meyer 2003; Siegel et al., 2003). 
The prior literature also questions the efficiency of TTOs as facilitators of research commercialization (Siegel et al., 2007; Wright et al., 2007; Kenney and Patton, 2009; Markman et al., 2005b; Aldridge and Audretsch, 2011; Perkmann et al., 2013).

Aldridge and Audretsch (2011), who studied a sample of highly productive scientists in the US found that $30 \%$ would choose a 'backdoor route' to commercialization. Although the process of direct market commercialization by researchers is complex and requires substantial financial resources, if the TTO is perceived as a barrier then the scientist will attempt to bypass it (Link et al. 2007). Broadman and Ponomariov (2009) applied the university perspective using the national survey of tenured and tenure-track scientists in the US "research intensive" sectors explain, why university scientists choose direct interactions with private companies in commercialization of 261 technology, instead of going a traditional TTO route (Siegel et al. 2004). In the context of post-socialist economies (Marozau and Guerrero, 2016), TTO face high level 263 of university bureaucracy, absence of economic motivation for TTO staff to commercialize 264 inventions, lack of financial resources to independently market technology, lack of freedom in 265 decision-making to acquire a patent, lack of industry engagement and networking (Kerr and Nanda, 266 2009; Yegorov, 2009). Altogether these factors create significant organizational filters to 267 knowledge transfer and spillover via TTOs (Siegel et al. 2003; Mowery et al., 2004; Powers and 268 McDougall, 2005; Mustar et al., 2006; Huyghe et al., 2016). Firstly, and the least of scientist's concern, disclosure of invention puts the novelty of the 270 invention at risk of reengineering and copying by competitors, if TTOs staff starts marketing the 271 invention before the IP protection is sought (Lockett and Wright, 2005; Berman, 2008). The pay272 scale in the public sector in transition economies limits the hiring of competent TTO staff and 273 economic motivation (Wright et al., 2008), which increases the risks of non-commercialization or 274 unintended knowledge outflows. 
Secondly, high level of bureaucracy and weak IP rights regulation may postpone application

276 for a patent and partner search (Siegel et al., 2003), increasing the time from the discovery to 277 adoption by industry.

Thirdly, complex and restrictive IP rights clauses included by university TTOs lawyers

discourage ecosystem stakeholders to collaborate (Freitas et al., 2013). When marketing technology

to industry, the TTO should be efficient in navigating conflicts of interests and values between a

281 scientist, university and a private firm (Slaughter and Rhoades, 2004), which rarely happens.

282 Monetary benefits are of great concern to both TTO and a firm, with TTOs having obtained IP

283 rights on patented technology may be hard to negotiate. A widely-used public university practice in 284 transition economies is to take away the IP right from the inventor (Marozau and Guerrero, 2016).

Fourthly, technology adoption typically requires ongoing collaboration with the inventor in order to commercialize technology, which may become difficult as inventor does not hold property rights and may refuse to collaborate. Unlike in the US, when university scientists receive federal grants (Bercovitz et al. 2001), in the transition economies, university receives government grants to serve large publicly-owned enterprises with new technology, where the economic interests of scientists are not considered (Marozau and Guerrero, 2016) and the invention is fully-owned by a university or a national government.

Fifthly, major part of university inventions are nascent in nature and "years away from commercialization" (Bradley et al. 2013: 586). The original invention may be significantly changed at adaptation and utilization stages with or without inventor's involvement in a process, increasing the uncertainty and risk for a TTO.

One of the interesting facts acknowledged in the recent TTO literature (Grimaldi et al. 2011; Siegel and Wessner, 2012; Kolympiris and Klein, 2017) is that universities may have few research results worth commercializing, in particular due to embryonic nature of technology which may require significant further modifications (Bradley et al. 2013). 
was little need for mechanisms of knowledge commercialization and IP right protection in a highly

302 centralized planning system with stable production chains (Yegorov, 2009). The regulation aiming

303 to encourage university knowledge transfer has now just begun to develop.

For example, Presidential Decree \#59 on the Commercialization of the Results of Scientific and Technological Activities Created at the Expense of Public Funds (Etalonline 2013), known as institutes and university R\&D expenditures are funded primarily from the state budget (66\%). Meanwhile funding from universities is negligible, accounting for less than $1 \%$ (Scienceportal, 2014). commercialization. accurately capture the complexities of the process. For example, the marketing of invention does not usually start before the TTO pursues a patent, TTO gauges the industry interest before investing resources into IP protection and further research (Bradley et al. 2013). In troubled transition economies with weak institutions and dominance of public sector in science, Etzkowitz's (2003) 
and Kenney and Patton's (2009) research commercialization models may not exactly work. First,

328 the ownership is never vested with an inventor to freely choose the commercialization route.

329 Second, inventor as a university employee may not receive a market price when contracting with

330 TTO. Third, loopholes in labor market regulation allow scientists to be full- or part-time employed 331 by a private firm (profit or non-for-profit) as well as perform entrepreneurial activities jointly with 332 industry (e.g. guest talks, paid consulting, technology transfer, copyrights, mentoring, supervising, 333 testing products). In these circumstances an alternative university knowledge transfer model is 334 applied. To formulate an alternative knowledge transfer model, Heinzl et al (2013) look into factors that can influence university technology transfer performance, such as research funding, organizational environment, ecosystem stakeholders and the mechanisms of technology transfer.

338 Financial resources to commercialize an invention is one of the biggest issues confronting scientists 339 (Kerr and Nanda 2009). It is widely acknowledged (Clarysse and Moray, 2004, 2006; Bekkers and 340 Freitas, 2008; Clarysse et al. 2011; Miller et al. 2014) that the direct industrial funding may provide 341 needed resources (Etzkowitz, 2003). The process starts from commercial and societal needs when 342 firms seek academic resources before contacting a university or scientist to commercialize the 343 technology (Van Rijnsoever et al. 2008). Except of private industry, who has already identified and use the technology (Aldridge and 345 Audretsch, 2011), other ecosystem stakeholders (e.g. banks and venture capitalists) are unlikely to 346 directly finance university research. This is due to the high risk and asymmetric information on the 347 market value of invention (Kerr and Nanda, 2009; Perkmann et al. 2011) and inability to market 348 invention (Sedaitis, 2000; Leydesdorff et al., 2015). Empirical precedents for assessing the impact of direct industrial funding of university technology have found that having industry grants increases the involvement of university scientists 351 in rapid technology development and collaboration with scientists working in private companies 352 (Bozeman and Gaughan, 2007), having industry grants increases the likelihood of interacting with 
private firms in any capacity, including informal knowledge exchanges as well as performance of entrepreneurial activities (Boardman and Ponomariov, 2009), having industry grants increases the favourable attitudes towards university-industry collaboration (Bogler 1994) as well as academic entrepreneurship activity and publication rates (Van Looy et al. 2004). The links and the degree of industry involvement is the result of individual and mutual choices in a two-sided market of scientists and private firms (Banal-Estanol et al, 2015).

Private companies identify technologies that they wants and directly fund research projects at universities (Van Looy et al. 2004; Perkmann et al. 2011b, 2013). Since industry pays for the research it has an interest in adopting the major research technologies (Wright et al., 2006). Also, firms aim at rapid commercialization and marketing an invention, because the benefits of innovation may depend on how quickly the product is adopted (Siegel et al. 2003, 2004).

In transition countries, direct industrial funding takes place through various channels: outsourcing part of industry research to university scientists (full- or part-time employment); scientist's employment at satellite firms of multinational companies (Zalewska-Kurek et al., 2016) or at headquarters and branches abroad; collaboration with industry scientists via guest talks, paid consulting, technology transfer, including transfer of special competences, access to special data, equipment and infrastructure, funds (Boardman and Ponomariov, 2009).

Direct industrial funding of university research is preferred for scientist in a transition economy for the following reasons. First is commercialization income. Public grants are normally given to low-risk applied research under strict requirements and with public or university ownership of the research outcomes, while direct industrial funding provides additional commercialization income, access to industry financial and technical resources, infrastructure, scientists and data (Melin, 2000; Díez-Vial and Montoro-Sánchez, 2016). Second is control. University ownership systems limits start-ups and spin-offs, as technology is publicly owned and its commercialization is limited (Damsgaard and Thursby, 2013). For example, if the research project is unsuccessful (if a new product does not start selling within three years of its invention), the research investment 
should be returned to the public sponsor (Etalonline 2013). Unlike public funding, direct industrial

380 funding has "negotiable" ownership systems on invention (e.g. scientists co-owns new technology).

381 Third is flexibility. Direct industrial funding makes it easier to modify the research results if

382 additional tasks or further adaptation is required (Bradley et al. 2013). This is unlikely with the 383 public grants with limited budgets, strict deadlines on invention and dissemination periods. Fourth

384 is networks. Direct industrial funding opens new possibilities for informal interactions, such as 385 further consulting and collaborative research while further development of technology (Broadman 386 and Ponomariov, 2009). Finally, it is co-ownership on invention. Commercialization agreement is 387 signed between a private company and an inventor (inventor-ownership system) (Perkmann and 388 Walsh, 2010; Hvide and Jones, 2016) and not between a private company and a TTO (university389 ownership system), when inventor may not be able to claim IP rights.. In the best possible contract 390 with industry, an inventor will receive a share in royalty on gross revenues or profits. Political actions aimed at encouraging knowledge transfers using direct industrial funding 392 have recently begun to develop further in transition economies (Bajmócy et al. 2010; Etalonline, 393 2013). We hypothesize: H2: In transition economies direct industrial funding facilitates knowledge transfer from university.

\subsection{Context of transition countries}

We test our hypotheses using individual scientist data from three economies: Belarus, Kazakhstan and Azerbaijan. They are rather peculiar, but representative transition economies.

400 Belarus has a small, open economy and is one of the very few 'soviet'-type countries left, which has 401 recently embarked on significant market reforms and support to information technology sector. 402 Meanwhile, Kazakhstan and Azerbaijan are transition economies largely based on natural resources 403 such as oil and gas. The economic and technological dynamics of these three economies depend to a 404 significant extent on the absorption of new foreign technologies and knowledge (Marozau and 
405 Guerrero, 2016). Multinational enterprises have started to be major actors in business R\&D with 406 developing linkages to university research.

Since 1991, Belarus, Kazakhstan and Azerbaijan have made greater efforts towards economic 408 openness, trade and investment in new universities, adoption of effective mechanisms for research 409 commercialization and market-based relations between research institutes, universities and 410 enterprises (Yegorov, 2009). They have inherited a relatively well-developed science and 411 technology system of the Soviet Union, however there is still a weak system of economic incentives 412 and research commercialization (Radosevic, 1998).

413 The economy of these countries is still significantly dominated by large public sector 414 enterprises in machinery, agriculture, oil and gas. Although Belarus has remained much more 415 'Soviet' than modern Russia, Kazakhstan or Azerbaijan, they are similar with regards to their 416 academic cultures, methods of public support and control over their education and research sectors, 417 government regulatory tools and control over industry and IP rights. Fewer universities compete 418 internationally for publications and international students, with research budgets predominately 419 spent on wages (Yegorov, 2009). Interestingly, unlike universities in Kazakhstan and Azerbaijan, 420 Belarusian universities that were established in the Soviet era have been preserved.

Analysis of knowledge commercialization in these countries as post-Soviet transition economies has important implications, and is relevant to other transition economies in the former 423 Soviet countries (Varblane et al. 2007b).

Overall, the higher education sector is unattractive for young people due to low wages, lack of academic freedom and public (university) ownership on invention. Scientists struggle to commercialize their inventions via a traditional model of university knowledge transfer, aiming to get a part-time employment at multinational firm research labs and collaborate with their scientists.

428 As in other transition countries such as Estonia (Mets, 2009), universities in Belarus, Azerbaijan 429 and Kazakhstan have problems attracting internationally recognized scholars. 
There are major differences between research commercialization in Belarus, Azerbaijan and

431 Kazakhstan and in catching-up economies such as Estonia, Hungary, Latvia and Lithuania. The

432 main difference is their ability to learn "how to..." and efficiently transfer technology to industry.

433 Research commercialization models applied in Estonia, Latvia and Lithuania have been tested in the

434 "West" and have become a new emerging institutions (Varblane et al., 2007b). In Estonia, for

435 example, research culture includes establishing and publishing in internationally peer-reviewed

436 journals, grant applications, , performance-based distribution of public research funding (Mets,

437 2009), which does not happen in Belarus, Kazakhstan or Azerbaijan. IP protection and national

438 innovation systems provide more incentives to knowledge transfer, for example in Estonia

439 (Varblane et al. 2007b). Unlike in transition economies, many Estonian universities accepted "the

440 entrepreneurial paradigm of the university in the triple helix of University- Industry-Government

441 relations (Mets, 2006). This demonstrates that universities have begun to encourage the

442 development of spin-off companies (Bray and Lee (2000) and to licence technologies to an

443 entrepreneur (e.g. inventor or external partner) (Phan and Siegel, 2006).

This is unlikely to happen at universities in Belarus, Kazakhstan and Azerbaijan, as TTOs do

not establish spin-offs and start-ups, rather they perform an information brokerage function between

446 a university and investors (Lerner, 2005). Collaboration with industry remains the preferred

447 channel of knowledge transfer. Collaboration with other ecosystem stakeholders is limited. First,

448 the government already funds research via national grants with public ownership on invention (not

449 attractive to scientists). Second. angel and venture capital investment is limited in transition

450 economies due to gaps in investor protection. In addition, most of university technologies are at

451 early stage, increasing the risk and uncertainty on investment. Third, collaboration with non-for-

452 profit is negligible and is biased towards foreign grants and academic engagement such as

453 volunteering work without technology transfer. Finally, scientists have little access to foreign

454 universities and institutions outside their countries, including language barrier and lack of networks

455 (Kenney and Patton, 2005). These are the reasons, why research commercialization by scientists in 
transition economies lags behind their Western counterparts, and that alternative knowledge commercialization models are in place (Kerr and Nanda, 2009; Boardman and Ponomariov, 2009; Kwiek, 2012).

$$
\text { Since existing innovation systems are still unable to link the knowledge creation to }
$$
knowledge commercialization (Varblane et al., 2007a, 2007b), the authorities made universities rather than scientists responsible for university knowledge transfer. Many universities responded on the call by establishing TTOs. This process was not fully thought through using the role models (Di Gregorio and Shane, 2003; Mustar et al., 2006; Chapple et al., 2005; Powers and McDougall, 2005;

Grimaldi et al. 2011; Mosey et al., 2017), when knowledge transfer mechanisms are linked to scientist incentives (Kenney and Patton, 2009; Perkmann et al. 2011b, 2013) facilitating the individual mechanism of the knowledge spillover of entrepreneurship. Traditional universities in Belarus, Kazakhstan and Azerbaijan were reluctant to change their practices, and responded with the development of personal networks with practitioners and research authorities, building large public consortia for collaboration contracts. The model of multilevel interactions between ecosystem stakeholders, university and scientists (Figure 1) was largely ignored (Degroof and Roberts, 2004; Audretsch, 2014). Consequently, the majority of scientists have been unaware of how to commercialize their research via TTO, and what are the implications of research commercialization: where to find customers and what exactly can and cannot be commercialized? Several legal prosecutions of scientists who informally collaborated with industry have been broadcast in the media in the 2000s, which was not conducive to academic entrepreneurship in a region (Yegorov, 2009). The main obstacles remain an underdeveloped entrepreneurship ecosystem (Grimaldi et al. 2011; Leydesdorff et al. 2015; Theodoraki and Messeghem, 2017), a lack of economic incentives (Guerrero et al. 2014, 2016), and financial resources (Tchalakov et al., 2010). 
The empirical analysis is based on a novel cross-sectional dataset constructed via online

483 survey over three years from November 2015 to August 2017 as the Academic entrepreneurship

484 survey for Belarus, Kazakhstan and Azerbaijan. Participation in the survey was optional. The data

485 collected in this study is the first attempt for generating statistics on university knowledge transfer

486 in transition economies which are not collected by official statistics or by university scientists or

487 TTOs. The online survey generated a comparatively small dataset that could be plagued by a non-

488 response bias or information disclosure bias.

The data has been thoroughly reviewed by the authors. Unique features of the survey include

sampling for representativeness at the level of regions in each country (at least one university in

each country region and two leading universities in capital-city), university ownership (a balanced

number of private/public universities), university size (medium and large) and field of study (at

493 least 4 different faculties within each university) and scientist academic position (junior and senior scientists). The scientific disciplines include mathematics, physics, medicine, chemistry,

engineering, agriculture, geosciences, economics and management, sports. The data was collected at 20 universities in three transition countries: Belarus ( 8 out of 35 universities with approx. $40 \%$ of professors' coverage), Kazakhstan (8 out of 61 universities with approx. 30\% of professors' coverage) and Azerbaijan (4 out of 28 universities with approx. $44 \%$ of professors' coverage). ${ }^{1}$ Table A1 in Appendix A provides a list of universities participated in the survey. These countries were selected building upon the societal clusters proposed by the Global Leadership and

501 Organizational Behavior Effectiveness research program (GLOBE) that groups countries on the 502 basis of cultural dimensions and similar institutions (Huyghe et al. 2016).

\footnotetext{
${ }^{1}$ We do not have full data on a sample distribution by university as it was not a mandatory question in the survey. The data does not allow us to identify individuals as neither university name, department name nor university email were mandatory answers. Moreover most researchers and faculty members in the countries in focus have Google or email boxes external to the university. We see it as a way to enable greater confidentiality and avoid disclosure. In order to maintain confidentiality, we left university name and email optional in addition to giving a no-disclosure promise. Very few researchers provided university names, but were more collaborative on Google and email accounts. We thank one anonymous reviewer for drawing our attention to explaining this.
} 
We started by collecting email and telephone information for the 4,705 established scientists

504 via the universities' web-pages by script with the help of the Phython programme. The records could generally be found by typing their full name, university and department. The ensuing e-mail accounts were then collected and registered in the scientist database. Of the 4,705 scientists identified and emailed, 2,602 responded. This means the initial response rate was 55.30 percent. 508 Only a subsample of individual observations were defined as academically active, and provided 509 information on commercialization income as a share of total income as well as other commercialization activity characteristics. As this might cause a selection bias, regressions based on 511 such survey responses are commonly estimated using a two-stage approach (Heckman, 1979). In 512 this, the subsequent second stage includes a control for unobserved determinants of selection 513 estimated in the first stage (Crépon et al., 1998). Consequently, when an individual does not 514 disclose income from commercialization it may mean they have an income, but do not wish to 515 disclose it, or that they do not know their own income. It would be incorrect to exclude these observations, because the estimation of specific individuals may be biased by the fact that the individual is not properly identified by commercialization income. In the approach used here 518 (Figure 2) both biases have to be accounted for. To address the disclosure bias we conducted a 519 probit regression on all 2,602 individuals identified:

$$
\text { Selection step one }: \operatorname{Pr}\left(\text { Disclosure }=1 \mid x_{i}^{1}\right)=\Phi\left(x_{i}^{1} \beta\right)
$$

where $x_{i}^{1}$ contains the variables capturing scientist age, position (associate professor, full professor, researcher) and the type of commercialization activity a scientist is involved in (e.g. honorarium, establishing a spin-off, licencing patents, product sales without spinoffs, public grants and spin-off establishment). We also include country and year fixed effects. Based on this regression, the Inverse Mill's ratio was calculated. It is included in the final outcome regression to control for the disclosure of commercialization information selection bias, also known as independence bias (Herstad and Ebersberger, 2015). 
By restricting this analysis to the 424 observations where the individuals all report

commercialization income (positive or zero), it is possible to use the additional information available from the survey to estimate the likelihood of an individual to be active or not active in research commercialization. There is a group of scientists which are involved in at least one type of commercialization activity, but report no commercialization. For those observations we define a “commercialization active" bias. We conducted a probit regression on 424 individuals identified:

$$
\text { Selection step two: } \operatorname{Pr}\left(\text { Active }=1 \mid x_{i}^{2}\right)=\Phi\left(x_{i}^{2} \beta\right)
$$

$$
\text { where } x_{i}^{2} \text { includes characteristics assumed to affect the decision to carry out }
$$
commercialization activities, including country and year fixed effects. This includes researcher's age, university ownership and the source of research financing (private, government, foreign, university or self-sponsorship) as well as type of external sponsor of research.

Furthermore, financing research should positively influence the propensity to engage in current commercialization activity (Kerr and Nanda, 2009). University ownership (private vs. public) may also influence the decision to engage in research commercialization as well as scientist's age (Crépon et al. 1998). Based on this selection regression a second Inverse Mill's ratio was calculated which was included in the final outcome regression. The correction of two selection biases by means of the three-step model employed here requires two instruments to produce credible estimates. In each stage, at least one variable has to determine selection without affecting the final or subsequent stages (Heckman, 1979; Green, 2000). The results of the selection equations are reported in Table A2 in Appendix A.

In Model 1 (Table A2), scientist age is measured as a natural logarithm as well as licencing patents. Professors and individuals involved in multiple forms of commercialization activity were found to be more likely to disclose their commercialization income.

It is notable no significant impact was detected from other types of commercialization activities on disclosure bias. In Model 2 (Table A2), individuals whose research was financed by 
foreign and government grants are more likely to be commercially active, while individuals who

self-sponsored their research were less likely to be actively commercialising their research.

In order to control for potential bias related to presence (or not) of TTO at university (not all continuous variable "TTO contracts" which illustrates a number of contracts signed via TTO in our empirical model. Once above variables are included the model will capture decision making on research commercialization by scientists located at universities with and without TTO. Our final from Kazakhstan.

Stage 1 (Model 1) Probit regression

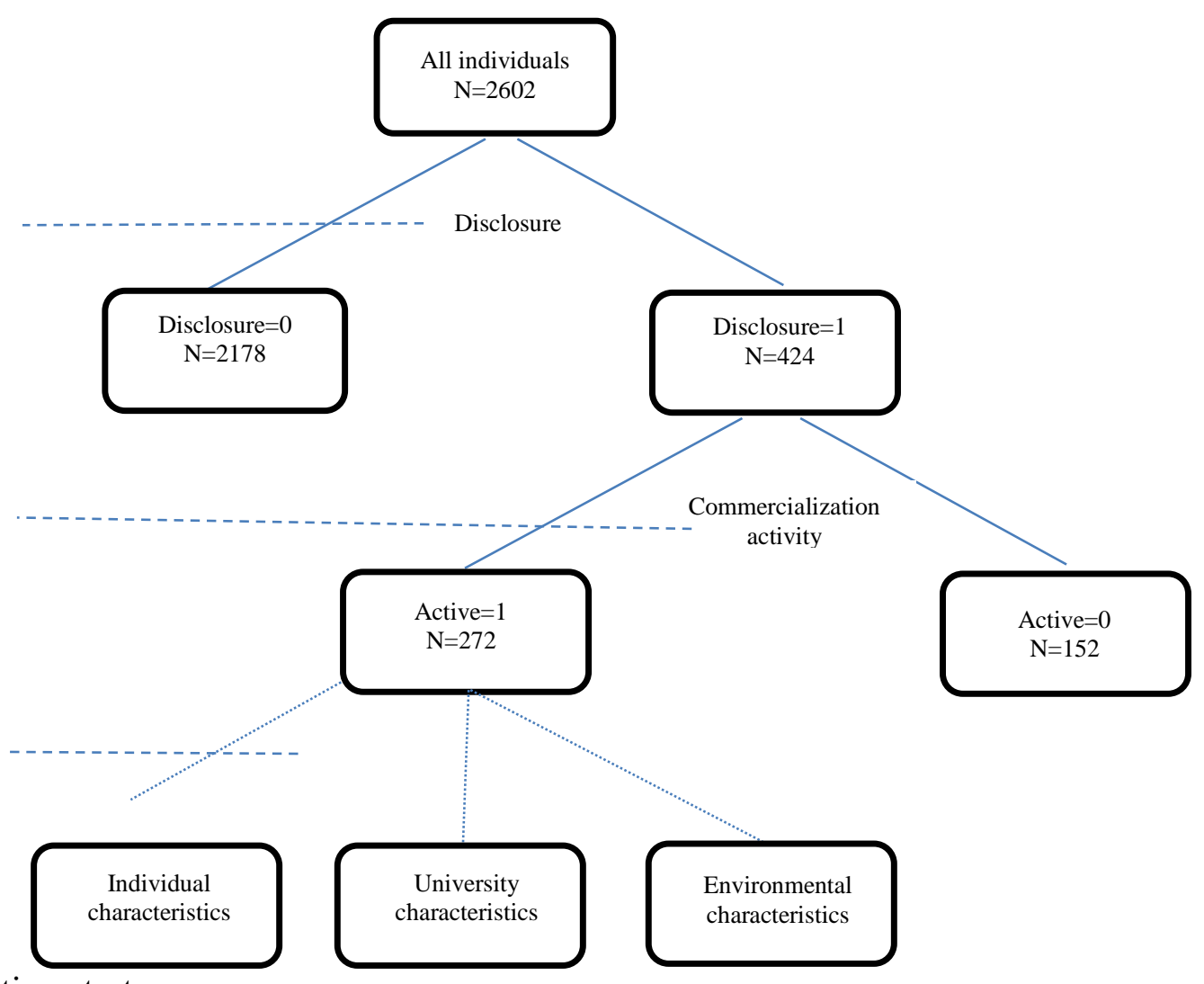

Figure 2: Estimation strategy

Stage 3

Logit regression

In most instances, we set up response deadlines and asked university administrators (Deans, Head of Schools, departments and where applicable deputy vice-chancellors) for assistance to disseminate survey questionnaires to increase the response rate. The survey targeted both nontenured and tenured academic staff (Muscio, 2010; Cunningham and Link, 2015). 
To support our quantitative approach we used a mixed-methods analysis which involved randomly selecting and face-to face interviewing scientists and TTO managers from the survey sample. We performed 27 face to face interviews (9 in Belarus, 14 in Kazakhstan and 4 in Azerbaijan) with university scientists and TTO managers during April 2016 - September 2017. Interviews were optional and strictly confidential. Appendix B1 describes the interview sample and 601 Appendix B2 introduces the interview protocol and eligibility criteria for respondents. The average age of the respondents was 47.5 years, average experience of research and teaching 22 years, and average commercialization rate being 23 percent in the income. With regards to administrative position and university ownership, 66 percent of respondents were members of the faculty board, 55 percent worked in public universities and 45 percent worked in private universities. Interestingly, only 44 percent of respondents used TTO services or had signed a contract with TTO.

A list of interviewees was created from the individuals who participated in a survey with and left their email willing to stay in touch. These were researchers, managers of business incubators, university technology transfer officers and professors. In addition, a snowball technique was used 611 during the interviews. In this case, the respondents were asked to mention other researchers they 612 knew to provide further opportunities to obtain data. We delineated the population of respondents 613 from these universities based on the following criteria. Firstly, the respondent needed to satisfy the 614 condition of commercialising knowledge and technology created at the university. Secondly, the 615 respondent had to be actively involved in various commercialization activities, with a share of 616 commercialization in total income being positive. Further, the respondent needed to collaborate 617 with at least one ecosystem stakeholder on research commercialization (e.g. university, government, 618 private industry rather than self-sponsoring his(her) research). We identified scientists in both junior senior positions who were competent to comment, 620 advise and suggest changes in research commercialization policy in these countries. They also 621 advised us on mechanisms and loopholes in the IP rights and academic entrepreneurship ecosystem, 
where scientists face significant challenges related to co-ownership of invention, engagement with

623 TTOs, private industry, government and adoption of research outcomes. Interviewees has advised which areas needed to be targeted by foreign investors interested in commercializing research outcomes in Belarus, Kazakhstan, Azerbaijan and economies-like.

\subsection{Variables}

To be included in a sample, all questions related to the variables of interest need to be completed with no missing values. All missing values and non-applicable answers were labelled as missing and therefore excluded from our sample. We proxy research commercialization activity with a share of scientist's annual income from commercialization activities in total income, which is 632 our dependent variable (Wright et al. 2007, 2009; Grimaldi et al. 2011; Siegel and Wright, 2015).

633 The resulting dependent variable was further scaled on the interval $[0,1]$ with the average of 0.14 634 (14\% of annual income from commercialization activity), the lowest share equal zero and the highest share of commercialization equals 0.90 which is $90 \%$ of annual income coming from 636 research commercialization. We applied a multi-level approach (Grimaldi et al., 2011; Guerrero and 637 Urbano, 2013; Miller et al. 2014; Theodoraki and Messeghem, 2017) to the process of research 638 commercialization with variables at ecosystem level, university (organizational level), and scientist 639 (individual level).

Our individual level control variables (CVs) build on Wright et al. (2007), Boardman and 641 Ponomariov (2009), Aldridge and Audretsch (2011), Grimaldi et al., (2011), Guerrero and Urbano 642 (2013) and Banal-Estañol et al. (2015) include: researcher's professional and personal 643 characteristics, such as number of works published in the last 5 years; academic position at the 644 university; share of research in total workload; self-sponsorship of research (if any). Individual level 645 has one explanatory variable (EV) which is individual's TTO awareness at university. TTO 646 awareness may reflect the scientist's level of engagement in commercialization. A positive 647 relationship suggests that TTO awareness would increase research commercialization. 

only become possible with adoption of the 'Belarusian Bayh-Dole act' (Etalonline 2013). university. Second is the number of contracts signed between a TTO and a scientist, which is a university-level variable. Drawing on Wright et al. (2007, 2008, 2009), Banal-Estanol et al. (2015) and MIT REAP framework (2017) ecosystem level CVs includes direct funding of research by ecosystem stakeholders such as government, industry, risk capital, foreign firms, non-for-profit (NGO) (Siegel et al. 2004; Bradley et al. 2013).

\footnotetext{
${ }^{2}$ As part of the ecosystem we also controlled for the following variables at country level: GDP per capita and population size (millions) from the World Bank development indicators; Global innovation index from the Global innovation index report; patent applications by residents and non-residents per 100,000 residents from the World Bank data and Corruption Perception Index from Transparency International. We used two-year lagged values for these variables to address the issue of endogeneity. Inclusion of these country controls has not changed the coefficient signs, confidence intervals or significance level in our the estimation model (3). Neither has it improved the model specification and goodness of fit, as all macroeconomic indicators were not statistically significant. This means that changes in the entrepreneurship ecosystem related to socioeconomic conditions, innovation and informal institutions do not change the degree of research commercialization by scientist. Our country dummies, which control for country fixed effects, were not statistically significant. We thus decided to keep country controls using the fixed effect approach (Green, 2002). We thank one anonymous reviewer for drawing our attention to this.
} 
Table 2: Description of dependent, independent and control variables.

\begin{tabular}{|c|c|c|c|c|c|}
\hline Variables & Variable description & Mean & St. dev & Min & Max \\
\hline \multicolumn{6}{|c|}{ Individual characteristics } \\
\hline $\begin{array}{l}\text { Commercialization } \\
\text { share (DV) }\end{array}$ & $\begin{array}{l}\text { Share of income, funds coming from commercializing } \\
\text { research, \% (on scale from zero to one) }\end{array}$ & 0.14 & 0.18 & 0.00 & 0.90 \\
\hline Published works & Number of works published in the last 5 years & 23.12 & 16.76 & 0.00 & 60.00 \\
\hline Researcher & Research fellow position equals one, zero otherwise & 0.13 & 0.34 & 0.00 & 1.00 \\
\hline Ass. Professor & Associate Professor position equals one, zero otherwise & 0.36 & 0.48 & 0.00 & 1.00 \\
\hline Research in workload & Share of research in total work $1-(0-25 \%)$ to $4(75-100 \%)$ & 1.73 & 0.81 & 1.00 & 4.00 \\
\hline Self-sponsor & Research is self-financed equals one, zero otherwise & 0.29 & 0.45 & 0.00 & 1.00 \\
\hline TTO awareness & $\begin{array}{l}\text { Researcher is aware of a TTO established at university equals } \\
\text { one, zero otherwise }\end{array}$ & 0.33 & 0.47 & 0.00 & 1.00 \\
\hline \multicolumn{6}{|c|}{ University characteristics } \\
\hline TTO contracts & Number of contracts signed via TTO & 0.46 & 1.41 & 0.00 & 8.00 \\
\hline TTO at university & TTO is established at university, zero otherwise & 0.64 & 0.48 & 0.00 & 1.00 \\
\hline Private university & Private university equals one, zero otherwise & 0.27 & 0.44 & 0.00 & 1.00 \\
\hline \multicolumn{6}{|c|}{ Environmental characteristics } \\
\hline University sponsor & Research is financed by university equals one, zero otherwise & 0.19 & 0.39 & 0.00 & 1.00 \\
\hline Industrial funding & $\begin{array}{l}\text { Direct industrial funding of research and technologies) equals } \\
\text { one, zero otherwise }\end{array}$ & 0.10 & 0.29 & 0.00 & 1.00 \\
\hline Foreign & $\begin{array}{l}\text { External stakeholder: foreign institutions (industry and } \\
\text { academia) equals one, zero otherwise }\end{array}$ & 0.25 & 0.43 & 0.00 & 1.00 \\
\hline Industry & $\begin{array}{c}\text { External stakeholder: industry and professional associations } \\
\text { equals one, zero otherwise }\end{array}$ & 0.18 & 0.39 & 0.00 & 1.00 \\
\hline University & $\begin{array}{l}\text { External stakeholder: other academic institutions equals one, } \\
\text { zero otherwise }\end{array}$ & 0.38 & 0.49 & 0.00 & 1.00 \\
\hline NGO & External stakeholder: NGOs equals one, zero otherwise & 0.12 & 0.33 & 0.00 & 1.00 \\
\hline Public & $\begin{array}{c}\text { External stakeholder: public institutions or government } \\
\text { equals one, zero otherwise }\end{array}$ & 0.22 & 0.41 & 0.00 & 1.00 \\
\hline Lambda 1 & The inverted Mills ratio for disclosure bias & 1.58 & 0.43 & 0.76 & 2.85 \\
\hline Lambda 2 & The inverted Mills ratio for commercialization active bias & 0.27 & 0.16 & 0.01 & 0.60 \\
\hline
\end{tabular}

671 Note: Number of researchers in final sample: 272.

672 Source: Academic entrepreneurship survey data for Belarus, Kazakhstan and Azerbaijan (collected 2015, 2016 and 2017). 
Table 3. Correlation matrix.

\begin{tabular}{|c|c|c|c|c|c|c|c|c|c|c|c|c|c|}
\hline & 1 & 2 & 3 & 4 & 5 & 6 & 7 & 8 & 9 & 10 & 11 & 12 & 13 \\
\hline 1 Commercialization share & 1 & & & & & & & & & & & & \\
\hline 2 Published works & -0.01 & 1 & & & & & & & & & & & \\
\hline 3 Researcher & 0.08 & $-0.18 *$ & 1 & & & & & & & & & & \\
\hline 4 Ass. Professor & -0.03 & $0.15^{*}$ & $-0.29 *$ & 1 & & & & & & & & & \\
\hline 5 Research in workload & 0.10 & $0.18^{*}$ & $0.16^{*}$ & -0.06 & 1 & & & & & & & & \\
\hline $6 \mathrm{TTO}$ contracts & 0.05 & -0.01 & $0.27 *$ & 0.02 & 0.11 & 1 & & & & & & & \\
\hline 7 TTO awareness & 0.01 & 0.08 & 0.11 & 0.02 & 0.10 & $0.40 *$ & 1 & & & & & & \\
\hline 8 TTO at university & 0.07 & 0.03 & $0.16 *$ & 0.01 & 0.02 & $0.24 *$ & $0.53 *$ & 1 & & & & & \\
\hline 9 Private university & -0.04 & -0.02 & -0.01 & -0.04 & -0.01 & 0.02 & 0.05 & 0.07 & 1 & & & & \\
\hline 10 University sponsor & -0.04 & 0.01 & -0.07 & -0.01 & -0.05 & $-0.13 *$ & 0.01 & 0.02 & 0.01 & 1 & & & \\
\hline 11 Industrial funding & $0.26^{*}$ & -0.03 & 0.09 & 0.01 & -0.03 & 0.09 & 0.03 & 0.01 & 0.01 & $-0.11 *$ & 1 & & \\
\hline 12 Self-sponsor & $-0.12 *$ & $-0.17^{*}$ & $-0.17^{*}$ & $0.13 *$ & -0.10 & -0.04 & $-0.14^{*}$ & $-0.12 *$ & $0.21 *$ & -0.06 & -0.07 & 1 & \\
\hline 13 Lambda 1 & $0.12 *$ & 0.02 & -0.06 & $0.13 *$ & 0.01 & 0.01 & 0.04 & 0.02 & 0.02 & -0.11 & $0.17 *$ & -0.01 & 1 \\
\hline 14 Lambda 2 & $-0.13 *$ & $-0.19 *$ & -0.07 & 0.05 & $-0.14 *$ & -0.08 & $-0.13^{*}$ & -0.08 & -0.10 & $0.17^{*}$ & $-0.18 *$ & $0.56 *$ & $-0.12 *$ \\
\hline
\end{tabular}

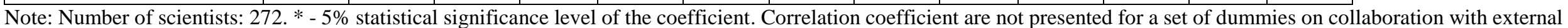
stakeholders (industry, foreign institutions, public institutions, NGO and university) to safe space.

Source: Academic entrepreneurship survey data for Belarus, Kazakhstan and Azerbaijan (collected 2015, 2016, 2017) 


\subsection{Estimation method.}

We started our analysis by applying a multilevel generalized linear model to estimate a fractional dependent variable. This was based on reports from individuals observed in the three consecutive waves for Belarus and Kazakhstan, and one wave for Azerbaijan. The sample is rotated, which means that individuals from one wave cannot be tracked in another, and the estimations through a pooled estimation makes distinguishing between temporal or sampling effects unfeasible. The selection of a multilevel estimation approach was based on the model introduced in Figure 1 with the variables describing individual, university (organizational) and ecosystem characteristics which affect the likelihood of research commercialization.

In a multilevel estimation, sometimes also called a hierarchical, random coefficient was not statistically significant. The data structure in the population was thus not identified as hierarchical (Goldstein, 2011). In other words, a multilevel generalized linear model was not feasible (Goldstein, 2011). This means that neither variation in university characteristics (specification 2 and 3 and 5 and 6, Table A3) nor variation in country characteristics (specification 1 and 4, Table A3) in each survey wave shaped research commercialization (Maas and Hox, 2005). Table A3 offers a robustness check of the multilevel estimation with the distribution of dependent variables (commercialization share) as binomial (specifications 1-3, Table A3) and Bernoulli (specifications proportions as dependent variables, we estimated the generalised logistic model with three-level controls and the fractional dependent variable $y_{i j k}$ defined on the interval $[0,1]$ such that:

$$
g\left[E\left(y_{i j k}\right)\right]=\beta_{0}+\beta_{1} x_{i j k}+\beta_{2} z_{i j k}+\beta_{3} \lambda_{i j k}+\varepsilon_{i j k}
$$


615 (2) and including them our final model (3) to control for selection bias. The presence and direction

616 of a selection bias was inferred from the statistical significance and sign of the Mill's ratio

617 coefficients in equation (3). Finally, $\varepsilon_{i j k}$ is an error term. Equation (3) includes year and country

618 fixed effects.

\section{Results}

\subsection{TTO and university research commercialization}

Table 4 provides the results of our model (3). Neither the establishment of the technology

transfer office nor the number of contracts established via the TTO nor TTO awareness had a

statistically significant impact on the commercialization share of scientist income, supporting H1

625 (Table 4 , spec. 1-3). The coefficient of TTO awareness $(\beta=0.605 ; p<0.12)$ is positive, but

at universities with and without a TTO. Predictive Margins with 95\% CIs in Fig.4 illustrate a

629 similar level of commercialization share for scientists having different number of

commercialization contracts with TTO. For example, scientists who have one or ten contracts with

631 TTO are likely to have a similar level of commercialization income. Predictive Margins with 95\%

632 CIs in Fig.5 illustrate that who were aware or unaware of TTOs existence at university have a

633 similar level of commercialization income.

634 Table 4: Generalised logistic model estimation with three-level controls

\begin{tabular}{|c|c|c|c|}
\hline Model specification & $(1)$ & (2) & (3) \\
\hline \multicolumn{4}{|c|}{ Individual characteristics } \\
\hline Published works & $\begin{array}{l}0.009 \\
(0.01)\end{array}$ & $\begin{array}{l}0.009 \\
(0.01)\end{array}$ & $\begin{array}{l}0.008 \\
(0.01)\end{array}$ \\
\hline Researcher & $\begin{array}{l}0.312 \\
(0.56)\end{array}$ & $\begin{array}{l}0.281 \\
(0.56)\end{array}$ & $\begin{array}{l}0.356 \\
(0.56)\end{array}$ \\
\hline Ass. Professor & $\begin{array}{c}0.626^{*} \\
(0.35)\end{array}$ & $\begin{array}{c}0.609^{*} \\
(0.35)\end{array}$ & $\begin{array}{l}0.625^{*} \\
(0.36)\end{array}$ \\
\hline Research in workload & $\begin{array}{c}-0.342 * \\
(0.19) \\
\end{array}$ & $\begin{array}{c}-0.358^{*} \\
(0.19) \\
\end{array}$ & $\begin{array}{c}-0.363^{*} \\
(0.20)\end{array}$ \\
\hline Self-sponsor & $\begin{array}{r}-0.599 \\
(0.47) \\
\end{array}$ & $\begin{array}{l}-0.645 \\
(0.46) \\
\end{array}$ & $\begin{array}{l}-0.601 \\
(0.47) \\
\end{array}$ \\
\hline TTO awareness (H1) & & & $\begin{array}{l}0.605 \\
(0.36) \\
\end{array}$ \\
\hline
\end{tabular}




\begin{tabular}{|c|c|c|c|}
\hline \multicolumn{4}{|l|}{ University characteristics } \\
\hline TTO at University (H1) & $\begin{array}{l}0.413 \\
(0.32)\end{array}$ & & \\
\hline TTO contracts $(\mathrm{H} 1)$ & & $\begin{array}{l}0.152 \\
(0.15) \\
\end{array}$ & \\
\hline Private university & $\begin{array}{l}-0.213 \\
(0.44) \\
\end{array}$ & $\begin{array}{l}-0.185 \\
(0.44) \\
\end{array}$ & $\begin{array}{l}-0.178 \\
(0.44) \\
\end{array}$ \\
\hline \multicolumn{4}{|l|}{ Environmental characteristics } \\
\hline University sponsor & $\begin{array}{c}-0.251 \\
(0.39)\end{array}$ & $\begin{array}{c}-0.191 \\
(0.39)\end{array}$ & $\begin{array}{c}-0.253 \\
(0.39)\end{array}$ \\
\hline Industrial funding $(\mathrm{H} 2)$ & $\begin{array}{c}1.778 * * \\
(0.91)\end{array}$ & $\begin{array}{c}1.782 * * \\
(0.91)\end{array}$ & $\begin{array}{c}1.764 * * \\
(0.90)\end{array}$ \\
\hline Foreign & $\begin{array}{l}-0.07 \\
(0.50)\end{array}$ & $\begin{array}{l}-0.05 \\
(0.51)\end{array}$ & $\begin{array}{l}-0.06 \\
(0.51)\end{array}$ \\
\hline Industry & $\begin{array}{l}-0.03 \\
(0.54)\end{array}$ & $\begin{array}{l}-0.01 \\
(0.54)\end{array}$ & $\begin{array}{l}-0.04 \\
(0.55)\end{array}$ \\
\hline University & $\begin{array}{c}0.26 \\
(0.47) \\
\end{array}$ & $\begin{array}{c}0.29 \\
(0.47) \\
\end{array}$ & $\begin{array}{c}0.32 \\
(0.48)\end{array}$ \\
\hline NGO & $\begin{array}{l}1.46^{* *} \\
(0.71) \\
\end{array}$ & $\begin{array}{c}1.47 * * \\
(0.71) \\
\end{array}$ & $\begin{array}{c}1.50 * * \\
(0.72)\end{array}$ \\
\hline Public & $\begin{array}{c}0.52 \\
(0.48) \\
\end{array}$ & $\begin{array}{c}0.48 \\
(0.48) \\
\end{array}$ & $\begin{array}{c}0.51 \\
(0.49) \\
\end{array}$ \\
\hline The inverse Mills ratio for disclosure bias & $\begin{array}{c}-0.651^{*} \\
(0.37)\end{array}$ & $\begin{array}{c}-0.658^{*} \\
(0.37)\end{array}$ & $\begin{array}{c}-0.663^{*} \\
(0.37)\end{array}$ \\
\hline $\begin{array}{l}\text { The inverse Mills ratio for commercialization } \\
\text { active bias }\end{array}$ & $\begin{array}{c}-2.534 * \\
(1.49)\end{array}$ & $\begin{array}{c}-2.614 * \\
(1.49)\end{array}$ & $\begin{array}{c}-2.467 * \\
(1.49)\end{array}$ \\
\hline country = Belarus & $\begin{array}{l}0.910 \\
(0.56) \\
\end{array}$ & $\begin{array}{c}0.986 \\
(0.56) \\
\end{array}$ & $\begin{array}{c}0.953 \\
(0.57) \\
\end{array}$ \\
\hline country = Kazakhstan & $\begin{array}{l}0.095 \\
(0.51)\end{array}$ & $\begin{array}{l}0.180 \\
(0.51)\end{array}$ & $\begin{array}{l}0.088 \\
(0.52)\end{array}$ \\
\hline Year 2016 & $\begin{array}{l}0.862 \\
(0.71) \\
\end{array}$ & $\begin{array}{l}0.941 \\
(0.71) \\
\end{array}$ & $\begin{array}{l}0.933 \\
(0.71) \\
\end{array}$ \\
\hline Year 2017 & $\begin{array}{c}1.185 * \\
(0.66)\end{array}$ & $\begin{array}{c}1.305 * * \\
(0.66)\end{array}$ & $\begin{array}{c}1.253^{*} \\
(0.65)\end{array}$ \\
\hline Constant & $\begin{array}{c}1.703 * \\
(0.99) \\
\end{array}$ & $\begin{array}{c}1.796 * \\
(0.98) \\
\end{array}$ & $\begin{array}{c}1.758 * \\
(0.98) \\
\end{array}$ \\
\hline Number of obs. & 272 & 272 & 272 \\
\hline LR chi2 & 41.16 & 40.73 & 42.45 \\
\hline Log-likelihood & -130.13 & -130.35 & -129.49 \\
\hline Pseudo R2 & 0.13 & 0.13 & 0.14 \\
\hline
\end{tabular}

635 Note: Number of scientists: 272. Reference year=2015; Reference country=Azerbaijan. .***,** and * Significance at 636 the $1 \%, 5 \%$ and $10 \%$ levels, respectively.

637 Source: Academic entrepreneurship survey data for Belarus, Kazakhstan and Azerbaijan (2015, 2016, 2017) 


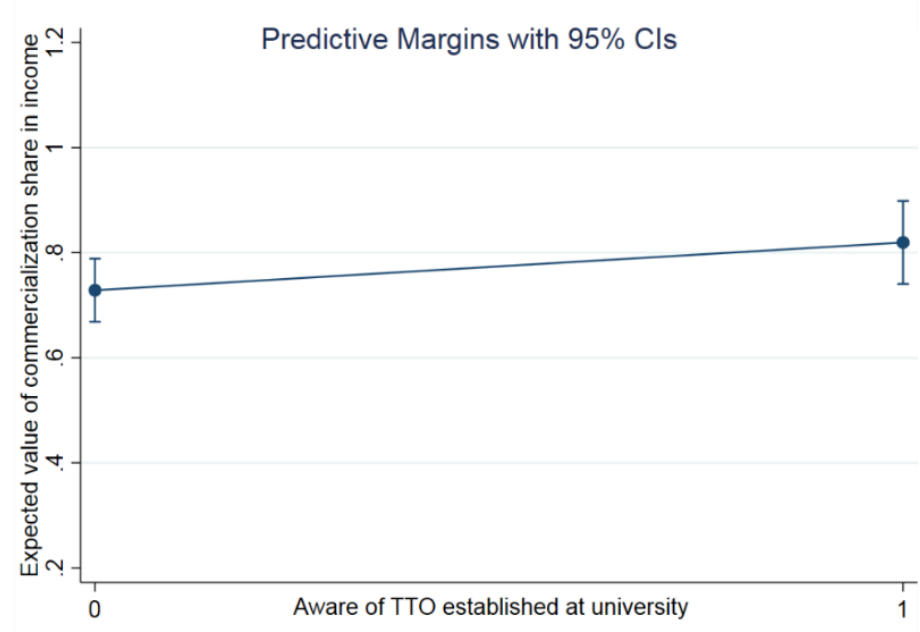
establishment at university

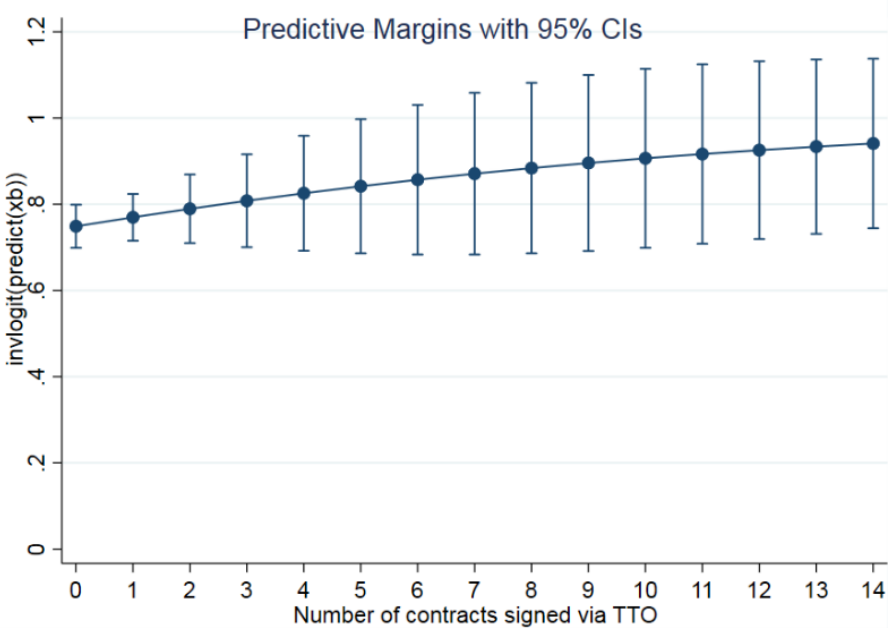
contracts established via TTO

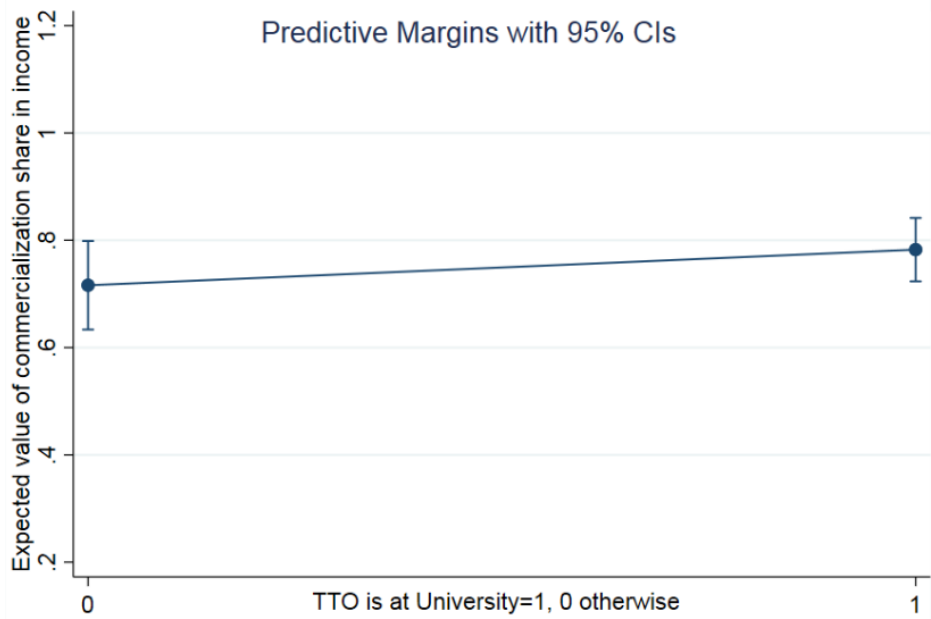

Figure 3: Predictive Margins with 95\% CIs: Expected commercialization rate and TTO

Figure 4: Predictive Margins with 95\% CIs: Expected commercialization rate and number of

Figure 5: Predictive Margins with 95\% CIs: Expected commercialization rate and TTO awareness 
The mixed method approach and 27 face-to-face interviews with TTO managers and scientists

649 were helpful in shedding more light on the role of TTOs in university knowledge transfer.

650 Interviewee four (I4) commented, "One of the reasons TTOs are not able to help scholars is the

651 institutional framework which is unfriendly in transition countries" confirming Yegorov (2009).

652 I(4) further laments: "TTOs in Belarus have highly bureaucratized rules and practices and lack

653 expert knowledge, and make it expensive to register contracts and run grants", supporting Link's et

654 al. (2007) findings. (I1) stated that, "TTOs are becoming university departments that process

655 documents for public funding and grants, and collect substantial shares of financing performing an

656 information broker to government, university and scientists, but not to investors (Lerner, 2005). (I5)

657 adds: "TTO for me equals bureaucracy" (Marozau and Guerrero, 2016). (I7) defended the

658 importance of TTOs at universities, but stated: "You need a person who collaborates with people in

659 the industry and with scientists. But such person is likely to be from a similar background that a

660 researcher to understand how a product works. An entrepreneur definitely needs to be an expert in

661 the product they manufacture. Companies that innovate need people even in marketing and other

662 areas who have PhDs in Physics, or in a very narrow specific field to understand it"(Lockett and

663 Wright, 2005; Berman, 2008). Hiring a competent TTO leader in transition economies is clearly an

664 issue (Wright et al., 2008).

In Azerbaijan the situation with TTOs is concerning. As (I27) commented, "Current state

legislation does not even allow universities or research institutions to use international grant funds.

In addition, one of the most challenging is the gap in the vision of top management with university departments as well as departments such as TTOs". This raises the importance of Kenney and

669 Patton's (2009) and Grimaldi's et al. (2011) argument regarding the creation of a regulation to 670 allow commercialization. Even though there are a number of highly-qualified researchers and 671 human resources at universities, the lack of understanding and vision of the top management 672 prevents successful research commercialization.

673 (I11) further adds to the efficiency of TTOs in transition economies: "Absolutely no 
competence at TTO. They do not have experience of working in business or industry. No market

675 intuition, innovative ideas or knowledge of how to commercialize technology" (Link et al. 2007;

676 Wright et al., 2008; Kolympiris and Klein, 2017). Regarding the new generation of TTOs, (I21)

677 adds: "We are the Bekturov Institute of Chemical Sciences in Kazakhstan and commercialize

678 medical chemistry research, development of new to market drugs, with enormous barriers of

679 commercialization in medical practice: no links with pharma private businesses, public and private

680 sponsorship of medical product trials is very low, which directly affects the willingness and interest

681 of medical graduates to work in the field of medical chemistry". (I2) also laments: "TTOs are

682 bureaucrats with [the] decision-making process depending on top university officials and

683 government priorities, not necessarily on what business needs. As a researcher I will go where [the]

684 money [is] when commercializing my research, private business is much of a help". This

685 demonstrates the importance of co-ownership on invention and direct collaboration with industry

686 (Boardman and Ponomariov, 2009)

Scientists reflecting on TTOs bureaucracy and inefficiencies have called for a new generation of TTOs which can develop a practice-based mix of offerings and to become an information broker for potential investors (Lerner, 2005)

(I10) highlights the role of cultural factors, which could not be captured easily captured with

691 the regression model, such as the use of English language in transition economies to communicate to foreigner investors and entrepreneurs. I(20) from Kazakhstan adds on the lack of networking

693 between university and business: "I have worked with a number of business schools, let's put it like 694 that. I've been totally underwhelmed at what I've seen. I've been going to them to market my 695 research and because I wanted a business community. The truth is most businesses know more than most business schools".

\subsection{Direct industrial funding and university research commercialization}

Direct industrial funding facilitates knowledge commercialization by scientists (Bogler, 1994; 
van Looy et al. 2004; Bozeman and Gaaughan 2007).(spec 1-3, Table 4). Fig. 6 illustrates the

701 expected value of research commercialization income under direct industrial funding (private 702 industry).

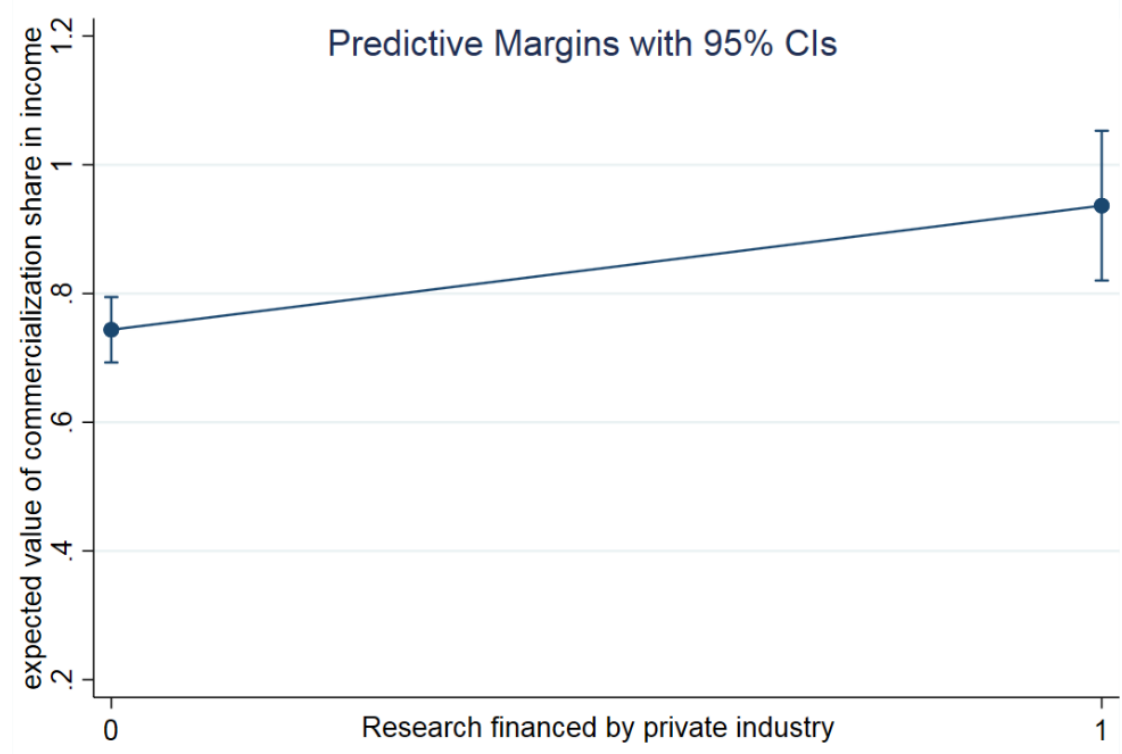

Figure 6: Predictive Margins with 95\% CIs: Expected commercialization rate and direct industrial funding.

Scientists who reported their external commercialization partner as industry have significantly higher level of commercialization income, supporting H2. Our findings also supports Kerr and Nanda (2009) and Aldridge and Audretsch (2011) for developed countries, when the lack of industrial funding constrains academic entrepreneurship.

Our interview results demonstrate that researchers do not consider TTOs to be helpful, and aim to bypass TTOs altogether by directly approaching industry direct (Link et al., 2007; Bozeman and Gaughan, 2007). (I10) stated: "I used to be very well connected to industry in Venezuela and with a few in the US, but here it has been really difficult to approach "the industry" to offer partnership due to the difficulty of communicating in English in much of the power and energy sector, which is my main area...I could, however, connect with foreign industries working in Kazakhstan, interested to adopt technology, but I have noticed they were only interested in providing services". TTOs at university should perform a stronger broker role for investors in marketing invention (Siegel et al. 2004; Cunningham and Link 2015; O'Kane et al. (2015). As 
suggested by I(20): "there are commercialization challenges with private industry in Kazakhstan. In

721 my opinion, the level of collaboration between science and industry is at its lowest, and in particular

722 in business and economics". This is puzzling as while university business schools are not engaged

723 in applied research, they could become facilitators of market development and compliment TTOs

724 (Aldridge and Audretsch, 2011; Audretsch, 2014). Several interviewees commented on direct

725 industrial funding in Belarus. (I2) comments: "It is hard to connect to industry if you do not have

726 networks, however those who manage may directly own the invention or share the ownership

727 between a sponsor - private industry and a scientists". (I2) further adds "Direct industrial funding is

728 more attractive here as it is faster, they are open and give more freedom of research and

729 experimentation, they involve you at each step of commercialization and pay royalty" (Melin, 2000;

730 Slaughter and Rhoades, 2004; Damsgaard and Thursby, 2013). Our interviews confirm that

731 scientists support the "Professor Privilege" -type system (Hvide and Jones, 2016) and wish it to be 732 adopted in transition economies.

teaching and commercialization results in a lower commercialization income $(\beta=-0.342-0.363$; $p<0.10)$, while being an associate professor increases commercialization income $(\beta=0.609-0.626$; $\mathrm{p}<0.05$ ) (Aldridge and Audretsch, 2011). Neither self-sponsoring research nor publication record is associated with research commercialization income, which contrast negative association found by Broadman and Ponomariov (2009). High number of publications may not necessarily correspond to

741 high-quality research in a transition context as most of publications target national and not international peer-reviewed journals.

At the organizational level, university ownership is not associated with research commercialization income. At the ecosystem level, university funding research does not change research commercialization income. Research funding by public institutions, foreign institutions 
and professional associations as well as academic partner institutions (outside the university) is not associated with research commercialization income. Collaboration with non-for-profits increases commercialization income $(\beta=1.46-1.50 ; \mathrm{p}<0.05)$, however, this type of collaboration usually includes paid consultancy and volunteering work, and is not associated with technology transfer to non-for-profit (Bercovitz et al. 2001). .

Ecosystem-level formal and informal institutions in Belarus, Kazakhstan and Azerbaijan were similar to each other in their impact on research commercialization income of scientists. An average scientist's commercialization income in 2017 was higher than in 2015. Inverse Mill's ratios for disclosure bias and commercialization active are negative and statistically significant. This demonstrates that respondents who did not answer the question on commercialization and were not included in our final sample were less likely to participate in commercialization activity and receive an income.

et al., 2005; Mustar et al., 2006; Grimaldi et al., 2011; Heinzl et al. 2013; Bradley et al. 2013)

forged through social capital measures and experience gained by serving on an advisory board, in the transition context they do not seem to play an important role. At the same time aspects of human capital such as academic position as well as personal characteristics of scientists such as age, publication record have little or no effect on commercialization income, either in the US (Aldridge and Audretsch, 2011) or in transition countries.

According to the existing literature (Thursby and Thursby, 2004; Perkmann et al. 2013;

768 Guerrero and Urbano, 2014, 2017) and in case of the troubled transition economies (Marozau and

769 Guerrero, 2016), we found that the universities' TTOs are limited in their legal and resource ability 770 to commercialize university research (Perkmann et al. 2013). Scientists at universities often treat 771 invention as a "public good" (Slaughter and Rhoades, 2004), hence the detect involvement of a 
scientist in a start-up or spin-off is unlikely. In contrast, private industry funds research it has

773 already identified to have high potential for commercialization. Since private industry pays for the 774 research it has an interest in adopting it as well as maintaining the legal ownership of research outcomes (Broadman and Ponomariov, 2009). U

Our finding demonstrates that direct industrial funding is the most efficient route of research commercialization by scientists as compared to disclosure, marketing and adaptation of technology via TTOs. We contend that TTO activity and direct industrial funding are not two successive steps, but may perform as two alternative models of knowledge transfer . This is an unexpected and interesting finding, which emphasizes the role of inventor-ownership on research outcomes in transition economies. The implementation of inventor-ownership mechanism in transition economies is challenging. This will require legal changes (e.g. IP regulation, co-ownership), creating university environment which is supportive to entrepreneurial activities (e.g. adjustment in teaching load, academic leadership and citizenship, funding conferences, academic visits, guest lectures, applied research and dissemination activities) (Kenney and Goe, 2004), in particular, TTOs should be granted greater independence from university and their leaders to be given more economic incentives to become a conduit of knowledge transfer.

To date, TTOs have become neither facilitators nor promoters of knowledge transfer and knowledge spillover from universities. This challenges the legitimacy of TTOs (O'Kane et al., 2015) as centres of knowledge transfer. Kenney and Patton (2009) found the system under which universities maintain the legal ownership of inventions is less than optimal in terms of economic efficiency and in advancing the private interests of commercialization. Our finding confirms it for transition economies.

We propose three alternatives that would address the current lack of scientists' engagement in research commercialization in transition contexts.

Our first proposal is to vest ownership with the inventor in a spirit of the "Professor Privilege" system. Investors should be free to contract with the university TTO or any other entity outside the 
university to support research commercialization. Inventor-ownership system was suggested by

799 Kenney and Patton (2009) and in recent works by Czarnitzki et al $(2015,2016)$ who found that 800 transition from an inventor-ownership to a university-ownership model decreased both the volume 801 and quality of patented inventions by university professors. Hvide and Jones (2016) found that the 802 abolishment of" Professor's Privilege" in Norway led to about a 50\% drop in the rate of start-ups by 803 university researchers. Policy makers who presumed that costs and risks of patenting and starting a 804 business were too high for individual inventors appeared to be wrong. Our second proposal is to sponsor open access to university research through public funds, without an exclusive right of a public sponsor, or a university, on research results in any sector and any university type. All inventions will be further contracted by the TTO if the establishment of a 808 legal relationship to further expand and validate the inventions is required by industry. It is also 809 important that all inventions should be licensed freely and non-exclusively. Unless sponsored 810 directly by private industry, neither universities TTO nor other public sponsor may hold exclusive 811 ownership of inventions (Powers and McDougall, 2005; Audretsch, 2014; Shu et al. 2014). Our third proposal is to support TTO's brokerage between junior university scientists and 813 industry (Perkmann et al., 2013). Junior scientists have less experience in marketing technology to 814 private industry and work with early stage technologies may benefit most by disclosing their 815 inventions to TTOs as the earlier stage of technology development (Lerner, 2005). Interviewee (I20) contributed to this discussion: "We need a commercialization platform to 817 engage researchers right through the university to industry. This is private industry which needs to 818 dictate [to] TTOs what problems need to be solved and what would they like to improve". These 819 measures will enhance participation of ecosystem stakeholders and TTOs in knowledge transfer. 820 Various crowdfunding platforms and angel investor funds have been established in collaboration 821 with the business schools in developed economies (Guerrero and Urbano, 2012, 2014; Belitski and Heron, 2017). If current structures cannot be created with the current competences on the basis of TTOs in transition economies, scientists, in particular more mature and with late-stage technologies 
will continue to bypass TTOs (Link et al., 2007). A new generation of TTOs should be integrated within business schools structures with private ownership on invention in case of successful fundraising . Finally, the effect of university support mechanisms should be more decisive (Kenney and Goe, 2004; Kwiek, 2012). "What makes a die-hard academic entrepreneur?" with 15 years overview of the academic entrepreneurship and knowledge transfer literature, the answer is very different to scientist entrepreneurs in transition economies.

\section{Conclusions.}

By asking scientists rather than university TTOs (Caldera and Debande, 2010) about the entrepreneurial activities they engage in and their commercialization income, a clear picture emerges for the research commercialization in transition economies. Firstly, a number of indications suggest that there is no relationship between the establishment of TTOs, TTO awareness, the number of contracts signed via a TTO and the extent of research commercialization. The former is not associated with individual characteristics such as scientist age, research output and quality or the self-sponsorship of research. Secondly, direct industrial funding is an effective conduit of knowledge transfer and knowledge spillover from universities, which may function as a substitute for public and angel finances. It is important that ownership is shared between an inventor and industry. Thirdly, the extent of research commercialization is less organisationally embedded and more ecosystem embedded with direct industrial funding plays the leading role in research commercialization (Boardman and Ponomariov, 2009; Grimaldi et al., 2011; Miller et al. 2014; Acs et al. 2017).

The empirical results from this study also suggest that more scientists engage in research commercialization in transition economies than in the US (Aldridge and Audretsch, 2011); however, only 13 percent of them are paid for knowledge transfers. This study makes the following contributions to academic entrepreneurship, entrepreneurship ecosystems and the KSTE literatures. 
First, adopting the TTO perspective of the KSTE and the stakeholder perspective to

entrepreneurship ecosystem framework, we investigate research commercialization by scientists in transition economies controlling for individual, university and ecosystem characteristics. The empirical results suggest, that commercialization income does not exactly mirror what has been found in the literature on academic entrepreneurship in developed economies (Wright et al., 2006, 2007; Kenney and Patton, 2005, 2009; Aldridge and Audretsch, 2011; Perkmann et al., 2011a, 2013).

Secondly, we develop a multi-level model of university research commercialization, which jointly examined the role of TTOs and direct industrial funding capital as a conduit of knowledge transfer from university in transition countries.

Thirdly, using unique primary data on scientists' entrepreneurial activity in three transition economies and controlling for various selection biases, this study provides important evidence for users / investors of academic research in transition economies. We demonstrate that university TTO, unlike direct industrial funding, has not yet become a conduit for knowledge transfer and spillover (Audretsch, 2014).

Responding to a call in the academic entrepreneurship literature (Kenney and Patton, 2009; university research commercialization across a broad spectrum of scientific fields, sizes, types of universities and in a different socioeconomic context. Whether this finding holds across broader groups of developing and transition economies as well as across more specific scientific fields and ecosystem stakeholders is an important issue that will be addressed in future research. et al. 2013; Guerrero and Urbano, 2013) of a variety of research commercialization models, such as establishing a spin-off, corporate entrepreneurship, paid consultancy and other (Muscio, 2010; particular organizational and ecosystem characteristics as well as scientist's capabilities that 
facilitate interactions with the industry, foreign firms, government and TTOs? Given a very limited

functions of TTOs in transition economies, it is unlikely we can expect any substantial effect of TTO activity on the valorization of research results. Implementation of the multi-level academic entrepreneurship ecosystem framework in future research (Perkmann et al. 2013; Acs et al. 2017) could be an answer to how research commercialization could be better facilitated by a variety of entrepreneurial ecosystem actors. It is also important to find an entrepreneurship ecosystem locus (city, region, country) with characteristics which are strongly associated with scientists' decisionmaking to commercialize research.

\section{References}

Abreu, M., Demirel, P., Grinevich, V., \& Karatas-Ozkan, M. (2016). Entrepreneurial practices in researchintensive and teaching-led universities. Small Business Economics. doi:10.1007/s11187-016-9754-5. Acs, Z.J, Audretsch, DB., \& Lehmann, E.E. (2013). The knowledge spillover theory of entrepreneurship. Small Business Economics 41(4), 757-774.

Acs, Z. J., Autio, E., \& Szerb, L. (2014). National systems of entrepreneurship: measurement issues and policy implications. Research Policy, 43(1), 476-494.

Acs, Z.J, Stam, E., Audretsch, DB., \& Connor, A. (2017). The lineages of the entrepreneurial ecosystem approach. Small Business Economics 49, 1-10.

Agarwal, R., Audretsch, D., \& Sarkar, M.B. (2010). Knowledge spillovers and strategic entrepreneurship. Strategic Entrepreneurship Journal, 4(4), 271-283.

Ankrah, S. and Al-Tabbaa, O. (2016). Social capital to facilitate 'engineered' university-industry collaboration for technology transfer: A dynamic perspective. Technological Forecasting and Social Change, 104, 1-15.

Aldridge, T. T., \& Audretsch, D. (2011). The Bayh-Dole act and scientist entrepreneurship. Research policy, 40(8), 1058-1067.

Algieri, B., Aquino, A., \& Succurro, M. (2013). Technology transfer offices and academic spin-off creation: the case of Italy. The Journal of Technology Transfer, 38(4), 382-400.

Arrow, K. (1962). Economic welfare and the allocation of resources for invention. In R. Nelson (Ed.), The rate and direction of inventive activity (pp. 609-626). Princeton, NJ: Princeton University Press. Audretsch, D., Lehmann, E., \& Warning, S. (2005). University spillovers and new firm location. Research Policy, 34(7), 1113-1122.

Audretsch, D., \& Keilbach, M. (2009). Resolving the knowledge paradox: Knowledge-spillover entrepreneurship and economic growth. Research Policy, 37(10), 1697-1705.

Audretsch D.B, \& Belitski, M. (2013). The missing pillar: The creativity theory of knowledge spillover entrepreneurship. Small Business Economics, 1-18.

Audretsch, D. B. (2014). From the entrepreneurial university to the university for the entrepreneurial society. The Journal of Technology Transfer, 39(3), 313-321.

Audretsch, D. B., \& Belitski, M. (2017). Entrepreneurial ecosystems in cities: establishing the framework conditions. The Journal of Technology Transfer, 42(5), 1030-1051.

Bajmócy, Z., Miklós L., \& Zsófia V. (2010). A subregional analysis of universities' contribution to economic and innovation performance." Transition Studies Review 17, 1: 134-150.

Banal-Estañol, A., Jofre-Bonet, M., \& Lawson, C. (2015). The double-edged sword of industry collaboration: Evidence from engineering academics in the UK. Research Policy, 44(6), 1160-1175.

Baum, C. F. (2008). Stata tip 63: Modeling proportions. Stata Journal, 8(2), 299.

Bekkers, R., \& Bodas Freitas, I. (2008). Analysing knowledge transfer channels between universities and 
industry: To what degree do sectors also matter? Research Policy, 37, 1837-1853.

Belitski, M., \& Heron, K. (2017). Expanding entrepreneurship education ecosystems. Journal of Management Development, 36(2), 163-177.

Bercovitz, J., Feldman, M., Feller, I., \& Burton, R. (2001). Organizational structure as a determinant of academic patent and licensing behaviour: an exploratory study of Duke, Johns Hopkins, and Pennsylvania state Universities. Journal of Technology Transfer, 26(1-2), 21-35.

Berman, E.P. (2008). Why did universities start patenting? institution-building and the road to the Bayh-Dole Act. Social Studies of Science 38 (6), 835-871.

Bishop, K., D’Este, P., \& Neely, A. (2011). Gaining from interactions with universities: multiple methods for nurturing absorptive capacity. Research Policy 40 (1), 30-40.

Boardman, P. C., \& Ponomariov, B. L. (2009). University researchers working with private companies. Technovation, 29(2), 142-153.

Bogler, R. (1994). University researchers' views of private industry: implications for educational administrators, academicians and the funding sources. Journal of Educational Administration 32 (2), 68-86. Bozeman, B., Gaughan, M. (2007). Impacts of grants and contracts on academic researchers' interactions with industry. Research Policy 36, 694-707.

Bradley, S. R., Hayter, C. S., \& Link, A. N. (2013). Models and methods of university technology transfer. Foundations and Trends® in Entrepreneurship, 9(6), 571-650.

Bray, M. J., \& Lee, J. N. (2000). University revenues from technology transfer: Licensing fees vs. equity positions. Journal of Business Venturing, 15(5), 385-392.

Chapple, W., Lockett, A., Siegel, D., \& Wright, M. (2005). Assessing the relative performance of UK university technology transfer offices: parametric and non-parametric evidence. Research Policy, 34(3), 369384.

Caldera, A., \& Debande, O. (2010). Performance of Spanish universities in technology transfer: An empirical analysis. Research Policy, 39(9), 1160-1173.

Carayol, N., \& Matt, M. (2004). Does research organization influence academic production? Laboratory level evidence from large European university. Research Policy, 33(8), 1081-1102.

Clarysse, B., \& Moray, N. (2004). A process study of entrepreneurial team formation: the case of a researchbased spin-off. Journal of Business Venturing, 19(1), 55-79.

Clarysse, B., Moray, N. (2006). Conceptualising the heterogeneity of research based spin-offs: a multidimensional taxonomy. Research Policy 35 (2), 289-308

Clarysse, B., Tartari, V., \& Salter, A. (2011). The impact of entrepreneurial capacity, experience and organizational support on academic entrepreneurship. Research Policy, 40(8), 1084-1093.

Cooke, P., Gomez Uranga, M., \& Etxebarria, G. (1997). Regional innovation systems: institutional and organizational dimensions. Research Policy, 26, 475-491.

Crépon, B., Duguet, E., \& Mairessec, J. (1998). Research, Innovation and Productivity: An Econometric

Analysis at The Firm Level. Economics of Innovation and new Technology, 7(2), 115-158.

Cunningham, J. A., \& Link, A. N. (2015). Fostering university industry R\&D collaborations in European Union countries. International Entrepreneurship and Management Journal 11(4), 849-860.

Czarnitzki, D., Doherr, T., Hussinger, K., Schliessler, P., Toole, A. (2015). Individual versus university ownership of university-discovered inventions. ZEW Discussion Paper 15-007. Mannheim

Czarnitzki, D., Doherr, T., Hussinger, K., Schliessler, P., \& Toole, A. A. (2016). Knowledge creates markets: The influence of entrepreneurial support and patent rights on academic entrepreneurship. European Economic Review, 86, 131-146.

Damsgaard. E.F. \& Thursby, M.C. (2013). University entrepreneurship and professor Privilege. Industrial and Corporate Change, 22(1), 183-218.

Dasgupta, P. \& David, P. (1994). Towards A New Economics of Science. Research Policy, $23(5), 487-521$. Degroof, J.J., \& Roberts, E.B. (2004). Overcoming weak entrepreneurial infrastructure for academic spin-off ventures. Journal of Technology Transfer 29 (3-4), 327-357.

Díez-Vial, I., \& Montoro-Sánchez, Á. (2016). How knowledge links with universities may foster innovation: The case of a science park. Technovation, 50, 41-52.

Di Gregorio, D., \& Shane, S. (2003). Why Some Universities Generate More TLO Start-Ups Than Others?. Research Policy, 32(2), 209-227.

Etalonline (2013). Presidential Decree \#59 on Commercialization of the Results of Scientific and Technological Activities Created at the Expense of Public Funds from 4/2/2013. Available at: http://etalonline.by/?type=text\&regnum=P31300059\#load_text_none_1_ 
Etzkowitz, H., Webster, A., Gebhardt, C. \& Cantisano B.R. (2000) The future of the university and the university of the future: evolution of ivory tower to entrepreneurial paradigm. Research Policy, 29, 313-330. Florida, R.L. \& Kenney, M. (1988). Venture Capital, High Technology and Regional Development. Regional Studies, 22(1), 33-48.

Etzkowitz, H. (2003). Research groups as 'quasi-firms': The invention of the entrepreneurial university. Research Policy 32(1), 109-121.

Freitas, I. M. B., Geuna, A., \& Rossi, F. (2013). Finding the right partners: Institutional and personal modes of governance of university-industry interactions. Research Policy, 42(1), 50-62.

Goldstein, H. (2011). Multilevel statistical models (Vol. 922). John Wiley \& Sons.

Green W. H. (2002). Econometric Analysis, 4th Edn. Prentice Hall, Upper Saddle River, NJ.

Grimaldi, R., Kenney, M., Siegel, D.S., \& Wright, M. (2011). 30 Years After Bayh-Dole: Reassessing Academic Entrepreneurship. Research Policy, 40(8), 1045-1057.

GSTU (2017). Technology Transfer Center. Gomel State Technical University. Available at : https://en.gstu.by/research/technology-transfer-center

Guerrero, M., \& Urbano, D. (2012). The development of an entrepreneurial university. The Journal of Technology Transfer 37(1), 43-74.

Guerrero, M., \& Urbano, D. (2014). Academics' start-up intentions and knowledge filters: An individual perspective of the knowledge spillover theory of entrepreneurship. Small Business Economics 43(1), 57-74. Guerrero, M., Urbano, D., \& Fayolle, A. (2016). Entrepreneurial activity and regional competitiveness: Evidence from European entrepreneurial universities. The Journal of Technology Transfer 41(1), 105-131. Guerrero, M., \& Urbano, D. (2017). The impact of Triple Helix agents on entrepreneurial innovations' performance: An inside look at enterprises located in an emerging economy. Technological Forecasting and Social Change, 119, 294-309.

Gulbrandsen, M., Smeby, J.C. (2005). Industry funding and university professors' research performance. Research Policy 34, 932-950

Heckman, J. J. (1979). Statistical models for discrete panel data. Chicago, IL: Department of Economics and Graduate School of Business, University of Chicago.

Heinzl, J., Kor, A. L., Orange, G., \& Kaufmann, H. R. (2013). Technology transfer model for Austrian higher education institutions. The Journal of Technology Transfer, 38(5), 607-640.

Herstad, S.J and Ebersberger, B. (2015). On the Link between Urban Location and the Involvement of Knowledge-Intensive Business Services Firms in Collaboration Network. Regional Studies, 49(7), 11601175 .

Huyghe, A., Knockaert, M., \& Obschonka, M. (2016). Unraveling the "passion orchestra" in academia. Journal of Business Venturing, 31(3), 344-364.

Hvide, H. K., \& Jones, B. F. (2016). University Innovation and the Professor's Privilege. National Bureau of Economic Research. No. w22057.

Jain, S., George, G., Maltarich, M. (2009). Academics or entrepreneurs? Investigating role identity modification of university scientists involved in commercialization activity. Research Policy, 38(6), 922-935. Kalar, B., \& Antoncic, B. (2015). The entrepreneurial university, academic activities and technology and knowledge transfer in four European countries. Technovation, 36, 1-11.

Kenney, M., Goe, R.W. (2004). The role of social embeddedness in professorial entrepreneurship: a comparison of electrical engineering and computer science at UC Berkeley and Stanford. Research Policy 33, 691-707.

Kenney, M., Patton, D. (2005). Entrepreneurial geographies: support networks in three high-tech industries. Economic Geography 81 (2), 201-228.

Kenney, M., Patton, D. (2009). Reconsidering The Bayh-Dole Act And The Current University Invention Ownership Model. Research Policy, 38(9), 1407-1422.

Kerr, W., Nanda, R., 2009. Financing constraints and entrepreneurship. National Bureau of Economic Research Working Paper no. 15498.

Korosteleva, J., \& Belitski, M. (2017). Entrepreneurial dynamics and higher education institutions in the postcommunist world. Regional Studies, 51(3), 439-453.

Kwiek, M. (2012). Universities and knowledge production in Central Europe. European Educational Research Journal, 11(1), 111-126.

Kolympiris, C., \& Klein, P. G. (2017). The Effects of Academic Incubators on University Innovation. Strategic Entrepreneurship Journal.

Lerner, J. (2005). The university and the start-up: Lessons from the past two decades. Journal of Technology 
1032

1033

1034

1035

1036

1037

1038

1039

1040

1041

1042

1043

1044

1045

1046

1047

1048

1049

1050

1051

1052

1053

1054

1055

1056

1057

1058

1059

1060

1061

1062

1063

1064

1065

1066

1067

1068

1069

1070

1071

1072

1073

1074

1075

1076

1077

1078

1079

1080

1081

1082

1083

1084

1085

1086

Transfer 30(1-2), 49-56.

Leydesdorff, L., Perevodchikov, E., \& Uvarov, A. (2015). Measuring triple-helix synergy in the Russian innovation systems at regional, provincial, and national levels. Journal of the Association for Information Science and Technology, 66(6), 1229-1238.

Link, A. N., \& Siegel, D. S. (2005). University-based technology initiatives: Quantitative and qualitative evidence. Research Policy, 34(3), 253-257.

Link, A.N., Siegel, D.S., Bozeman, B. (2007). An empirical analysis of the propensity of academics to engage in informal university technology transfer. Industrial and Corporate Change 16 (4), 641-655.

Lockett, A., Wright, M., Franklin, S. (2003). Technology Transfer And Universities' Spinout Strategies. Small Business Economics, 20(2), 185-200.

Lockett, A., \& Wright, M. (2005). Resources, Capabilities, Risk Capital And The Creation Of University SpinOut Companies. Research Policy, 34(7), 1043-1057.

Maas, C. J., \& Hox, J. J. (2005). Sufficient sample sizes for multilevel modeling. Methodology, 1(3), 86-92.

Markman, G., Gianiodis, P., Phan, P., \& Balkin, D. (2005a). Innovation Speed: Transferring University Technology to Market. Research Policy, 34(7), 1058-1075.

Markman, G.D., Phan, P.H., Balkin, D.B., Gianiodis, P.T. (2005b). Entrepreneurship and university-based technology transfer. Journal of Business Venturing 20, 241-263

Marozau, R., \& Guerrero, M. (2016). Conditioning factors of knowledge transfer and commercialisation in the context of post-socialist economies: the case of Belarusian higher education institutions. International Journal of Entrepreneurship and Small Business, 27(4), 441-462.

Melin, G. (2000). Pragmatism and self-organization: research collaboration on the individual level. Research Policy 29, 31-40.

Meyer, M. (2003). Academic Patents As An Indicator Of Useful Research? A New Approach To Measure Academic Inventiveness. Research Evaluation, 12(1), 17-27.

Mets, T (2006). Creating a knowledge transfer environment. Management Research News, 29(12), 754 - 768

Mets, T. (2009). Creating business model for commercialization of university research. Organizacijø Vadyba: Sisteminiai Tyrimai, (51), 83.

Miller, K., McAdam, M. \& McAdam, R. (2014). The changing university business model: a stakeholder perspective. R\&D Management 44(3), 265-287.

MIT REAP (2017). The MIT Regional Entrepreneurship Acceleration Program (MIT REAP). Available at: http://reap.mit.edu/about/

Mosey, S., Guerrero, M., \& Greenman, A. (2017). Technology entrepreneurship research opportunities: insights from across Europe. The Journal of Technology Transfer, 42(1), 1-9.

Mowery, D.C., Nelson, R.R., Sampat, B.N., \& Ziedonis, A.A. (2004). Ivory Tower and Industrial Innovation: University-Industry Technology Before and After the Bayh-Dole Act in the United States. Stanford University Press, Stanford.

Muscio, A. (2010). What Drives The University Use Of Technology Transfer Offices? Evidence From Italy. The Journal Of Technology Transfer, 35(2), 181-202.

Mustar, P., Renault, M., Colombo, M.G., Piva, E., Fontes, M., Lockett, A., Wright, M., Clarysse, B. \& Moray, N. (2006). Conceptualising the heterogeneity of research-based spin-offs: A multi-dimensional taxonomy. Research policy, 35(2), 289-308.

O’Kane, C., Mangematin, V., Geoghegan, W., \& Fitzgerald, C. (2015). University technology transfer offices: The search for identity to build legitimacy. Research Policy, 44(2), 421-437.

Perkmann, M., \& Walsh, K. (2010). How firms source knowledge from universities: Partnerships versus contracting. In Bessant, J., \& Venables, T. (Eds.), Creating wealth from knowledge: meeting the innovation challenge. Cheltenham: Edward Elgar (273-297).

Perkmann, M., King, Z., \& Pavelin, S. (2011a). Engaging excellence? Effects of faculty quality on university engagement with industry. Research Policy, 40, 539-552.

Perkmann, M., Neely, A., \& Walsh, K. (2011b). How should firms evaluate success in university-industry alliances? A performance measurement system. R\&D Management, 41, 202-216.

Perkmann, M., Tartari, V., Mckelvey, M., Autio, E., Brostro“m, A., D’este, P., et al. (2013). Academic engagement and commercialisation: A review of the literature on university -industry relations. Research Policy, 42, 423-442.

Phan, P.H., \& Siegel, D.S. (2006). The Effectiveness Of University Technology Transfer. Foundations and Trends In Entrepreneurship, 2(2), 77-144. 
1087

1088

1089

1090

1091

1092

1093

1094

1095

1096

1097

1098

1099

1100

1101

1102

1103

1104

1105

1106

1107

1108

1109

1110

1111

1112

1113

1114

1115

1116

1117

1118

1119

1120

1121

1122

1123

1124

1125

1126

1127

1128

1129

1130

1131

1132

1133

1134

1135

1136

1137

1138

1139

1140

1141

Powers, J.B., \& Mcdougall, P. (2005). University Start-Up Formation And Technology Licensing With Firms That Go Public: A Resource Based View Of Academic Entrepreneurship. Journal of Business Venturing, 20(3), 291-311.

Radosevic, S. (1998). The transformation of national systems of innovation in Eastern Europe: between restructuring and erosion. Industrial and corporate change, 7(1), 77-108.

Scienceportal (2014). Science, Technologies and Innovations in Belarus. Available at:

http://scienceportal.org.by/en/science/

Sedaitis, J. (2000). Technology transfer in transitional economies: a test of market, state and organizational models. Research Policy, 29(2), 135-147.

Shu, C., Liu, C., Gao, S., \& Shanley, M. (2014). The knowledge spillover theory of entrepreneurship in alliances. Entrepreneurship Theory and Practice, 38(4), 913-940.

Siegel, D.S., Waldman, D.A., Atwater, L.E., \& Link, A.N. (2003). Commercial Knowledge Transfers From Universities To Firms: Improving The Effectiveness Of University-Industry Collaboration. The Journal Of High Technology Management Research, 14(1), 111-133.

Siegel, D. S., Waldman, D. A., Atwater, L. E., \& Link, A. N. (2004). Toward a model of the effective transfer of scientific knowledge from academicians to practitioners: qualitative evidence from the commercialization of university technologies. Journal of engineering and technology management, 21(1-2), 115-142.

Siegel, D.S., Wright M., \& Lockett A. (2007). The Rise Of The Entrepreneurial Activities At Universities: Organizational And Societal Implications. Industrial and Corporate Change, 16(4), 489-504.

Siegel, D., \& Wessner, C. (2012). Universities and the success of entrepreneurial ventures: Evidence from the small business innovation research program. Journal of Technology Transfer, 37, 404-415.

Siegel, D. S., \& Wright, M. (2015). Academic Entrepreneurship: Time for a Rethink? British Journal of Management, 26(4), 582-595.

Slaughter, S. \& Rhoades, G. (2004). Academic Capitalism and the New Economy: Markets, States and Higher Education. Baltimore: Johns Hopkins University Press.

So, A.D., Sampat, B.N., Rai, A.K., Cook-Deegan, R., Reichman, J.H., Weissman, R., et al. (2008) Is BayhDole Good for Developing Countries? Lessons from the US Experience. PLoS Biol 6(10): e262.

Stam, E. (2015). Entrepreneurial ecosystems and regional policy: a sympathetic critique. European Planning Studies. 1-11.

Stam, E., \& Spigel, B. (2017). Entrepreneurial ecosystems. In R. Blackburn, D. De Clercq, J. Heinonen, \& Z. Wang (Eds.), The SAGE Handbook of Small Business and Entrepreneurship. London: SAGE

Tchalakov, I., Mitev, T., \& Petrov, V. (2010). The academic spin-offs as an engine of economic transition in Eastern Europe. A path-dependent approach. Minerva, 48(2), 189-217.

Theodoraki, C., \& Messeghem, K. (2017). Exploring the entrepreneurial ecosystem in the field of entrepreneurial support: a multi-level approach. International Journal of Entrepreneurship and Small Business, 31(1), 47-66.

Thursby, J., Thursby, M. (2004). Are faculty critical? Their role in the university-industry licencing. Contemporary Economic Policy 22(2), 162-169

Urbano, D., \& Guerrero, M. (2013). Entrepreneurial universities: Socio-economic impacts of academic entrepreneurship in a European region. Economic Development Quarterly, 27(1), 40-55.

Yegorov, I. (2009). Post-Soviet science: Difficulties in the transformation of the R\&D systems in Russia and Ukraine. Research Policy, 38(4), 600-609.

Van Looy, B., Ranga, M., Callaert, J., Debackere, K., Zimmermann, E. (2004). Combining entrepreneurial and scientific performance in academia: towards a compounded and reciprocal Matthew-effect? Research Policy 33 (3), 425-441

van Rijnsoever, F. J., Hessels, L. K., \& Vandeberg, R. L. J. (2008). A resource-based view on the interactions of university researchers. Research Policy, 37, 1255-1266.

Varblane, U., Dyker, D., \& Tamm, D. (2007a). How to improve the national innovation systems of catchingup economies?. Trames, 11(2), 106-123.

Varblane, U., Dyker, D., Tamm, D., \& von Tunzelmann, N. (2007b). Can the National Innovation Systems of the New EU Member States Be Improved? Post-Communist Economies, 19(4), 399-416.

WIPO (2018) World Intellectual Property Organization. Country statistics. Available at: http://www.wipo.int/ipstats/en/statistics/country_profile

Wright, M., Clarysse, B., Lockett, A., \& Binks, M. (2006). Venture Capital And University Spin-Outs. Research Policy, 35(4), 481-501. 
1142 Wright, M., Clarysse, B., Mustar, P., \& Lockett, A. (2007). Academic entrepreneurship in Europe. 1143 Massachusetts, US: Edward Elgar Publishing.

1144 Wright, M., Clarysse, B., Lockett, A., \& Knockert, M. (2008). Mid-range universities' in Europe linkages with 1145 industry: knowledge types and the role of intermediaries. Research Policy 37 (8), 1205-1223.

1146 Wright, M., Piva, E., Mosey, S., Lockett, A. (2009). Business schools and academic entrepreneurship. Journal 1147 of Technology Transfer 34 (6), 560-587.

1148 Zalewska-Kurek, K., Kandemir, S., Englis, B. G., \& Englis, P. D. (2016). Development of market-driven 1149 business models in the IT industry. How firms experiment with their business models? Journal of Business 1150 Models, 4(3), 48. 


\section{Appendix A}

Table A1: The list of universities participated in the survey and interviews

\begin{tabular}{|c|c|c|c|c|c|}
\hline Country & Institution & $\begin{array}{c}\text { Webometrics } \\
\text { ranking of } \\
\text { University }\end{array}$ & $\begin{array}{l}\text { Pre-1991 } \\
\text { University }\end{array}$ & $\begin{array}{l}\text { Technical } \\
\text { University }\end{array}$ & $\begin{array}{l}\text { TTO } \\
\text { established }\end{array}$ \\
\hline \multirow{8}{*}{ Belarus } & Belarusian State University & 1 & Yes & No & Yes \\
\hline & Belarusian State Economic University & 9 & Yes & No & No \\
\hline & Belarusian National Technical University & 2 & Yes & Yes & Yes \\
\hline & $\begin{array}{l}\text { Belarusian State University of Informatics } \\
\text { and Radioelectronics }\end{array}$ & 5 & Yes & Yes & Yes \\
\hline & Polessky State University & 11 & No & No & No \\
\hline & Polotsk State University & 16 & Yes & Yes & No \\
\hline & Belarusian State Technological University & 6 & Yes & Yes & Yes \\
\hline & Belarusian State Agricultural Academy & 30 & Yes & No & No \\
\hline \multirow{8}{*}{ Kazakhstan } & Nazarbayev University & 5 & Yes & Yes & Yes \\
\hline & Kazakh-British Technical University & 11 & Yes & Yes & Yes \\
\hline & KIMEP University & 9 & No & No & Yes \\
\hline & Kazakh National Technical University & 3 & Yes & Yes & Yes \\
\hline & Narhoz University & 9 & Yes & No & Yes \\
\hline & Turan University & 54 & No & No & No \\
\hline & $\begin{array}{l}\text { Akhmet Yassawi International Kazak- } \\
\text { Turkish university }\end{array}$ & $\mathrm{n} / \mathrm{a}$ & No & No & Yes \\
\hline & Innovative Eurasian University & 35 & No & No & Yes \\
\hline \multirow{4}{*}{ Azerbaijan } & Baku State University & 1 & Yes & Yes & Yes \\
\hline & $\begin{array}{l}\text { Azerbaijan University of Architecture and } \\
\text { Construction }\end{array}$ & 13 & Yes & Yes & No \\
\hline & Baku Engineering University & 5 & No & Yes & Yes \\
\hline & Khazar University & 3 & No & No & No \\
\hline
\end{tabular}


Table A2: Selection models.

\begin{tabular}{|c|c|c|c|c|c|c|}
\hline \multirow{2}{*}{ Two-step Heckman approach } & \multicolumn{3}{|c|}{ Model 1: Disclosure=1 } & \multicolumn{3}{|c|}{ Model 2: Active=1 } \\
\hline & $\mathrm{dx} / \mathrm{dy}$ & SE & $\begin{array}{l}\text { Marginal } \\
\text { effects }\end{array}$ & $\mathrm{dx} / \mathrm{dy}$ & SE & $\begin{array}{l}\text { Marginal } \\
\text { effects }\end{array}$ \\
\hline Age $(\log )$ & 1.01 & $0.38 * * *$ & 3.71 & 0.26 & 0.29 & 3.71 \\
\hline Researcher $=1,0$ otherwise & 0.24 & 0.25 & 0.14 & & & \\
\hline Ass. Professor $=1,0$ otherwise & -0.34 & $0.21 *$ & 0.35 & & & \\
\hline Full professor $=1,0$ otherwise & -0.16 & 0.30 & 0.18 & & & \\
\hline Comm. activity: honorarium $=1,0$ otherwise & 0.28 & 0.19 & 0.33 & & & \\
\hline Comm. activity: establishing spin-off $=1,0$ otherwise & -0.49 & 0.41 & 0.08 & & & \\
\hline Comm. activity: licencing patents $=1,0$ otherwise & 0.57 & $0.37 *$ & 0.06 & & & \\
\hline Comm. activity: product sales $=1,0$ otherwise & -0.17 & 0.24 & 0.18 & & & \\
\hline Research financed by foreign grants $=1,0$ otherwise & & & & 0.89 & $0.34 * *$ & 0.13 \\
\hline Research financed by government grants $=1,0$ otherwise & & & & 0.39 & $0.20 * *$ & 0.34 \\
\hline Research financed by private industry $=1,0$ otherwise & & & & 0.27 & 0.34 & 0.08 \\
\hline Research self-financed $=1,0$ otherwise & & & & -0.35 & $0.19 *$ & 0.35 \\
\hline Private university $=1,0$ otherwise & & & & 0.27 & 0.19 & 0.24 \\
\hline $\begin{array}{l}\text { Country dummies (reference country=Azerbaijan) } \\
\text { Year dummies (reference year=2005) }\end{array}$ & \multicolumn{3}{|c|}{$\begin{array}{l}\text { Yes } \\
\text { Yes }\end{array}$} & \multicolumn{3}{|c|}{$\begin{array}{l}\text { Yes } \\
\text { Yes }\end{array}$} \\
\hline $\begin{array}{c}\text { Number of obs. } \\
\text { Likelihood ratio test Wald chi2 } \\
\text { Prob }>\text { Chi2 } \\
\text { Pseudo-R2 }\end{array}$ & \multicolumn{3}{|c|}{$\begin{array}{c}2602 \\
47.5 \\
0.00 \\
0.126\end{array}$} & \multicolumn{3}{|c|}{$\begin{array}{c}424 \\
36.28 \\
0.00 \\
0.100\end{array}$} \\
\hline
\end{tabular}

1160 Note: Marginal effects and robust standard errors from probit regression model are shown. ${ }^{* * *},{ }^{* *}$ and ${ }^{*}$ Significance at the $1 \%, 5 \%$ and

$116110 \%$ levels, respectively. Both models include year controls, which are jointly significant. Model 1 and Model 2 the inverse Mills ratios

1162 calculated are used on the final stage to predict commercialization share. Reference category for commercialization activity=multiple

1163 commercialization activity. Reference category for commercialization activity=multiple commercialization activity. Reference category for

1164 research financing= multiple sources of finance.

1165 Source: Academic entrepreneurship survey data for Belarus, Kazakhstan and Azerbaijan (collected 2015, 2016 and 2017).

1166

1167 
Table A3: Mixed-effects GLM: Country and university level effects on scientist's research commercialization activity. DV: Commercialization share in income standardized $[0,1]$

\begin{tabular}{|c|c|c|c|c|c|c|}
\hline Specification & (1) & (2) & (3) & (4) & (5) & (6) \\
\hline Dep. variable distribution & \multicolumn{3}{|c|}{ Binomial } & \multicolumn{3}{|c|}{ Bernoulli } \\
\hline Constant & $\begin{array}{c}1.149 * * * \\
(0.21)\end{array}$ & $\begin{array}{c}1.167 * * * \\
(0.16)\end{array}$ & $\begin{array}{c}1.167 * * * \\
(0.16)\end{array}$ & $\begin{array}{c}1.169 * * * \\
(0.17)\end{array}$ & $\begin{array}{c}1.167 * * * \\
(0.16)\end{array}$ & $\begin{array}{c}1.167 * * * \\
(0.16)\end{array}$ \\
\hline Variance (country level) & $\begin{array}{c}0.0604 \\
(0.11)\end{array}$ & & & $\begin{array}{c}0.01 \\
(0.07)\end{array}$ & & \\
\hline Variance (university level - size) & & $\begin{array}{c}0.00 \\
(0.00)\end{array}$ & & & $\begin{array}{c}0.00 \\
(0.00)\end{array}$ & \\
\hline Variance (university level - ownership) & & & $\begin{array}{l}0.00 \\
(0.00)\end{array}$ & & & $\begin{array}{l}0.00 \\
(0.00)\end{array}$ \\
\hline $\mathrm{N}$ & 272 & 272 & 272 & 272 & 272 & 272 \\
\hline LR test vs. logistic model (chi2) & 0.77 & 0.00 & 0.00 & 0.01 & 0.00 & 0.00 \\
\hline p-value (chi 2) & 0.18 & 0.98 & 0.98 & 0.18 & 0.98 & 0.98 \\
\hline Log-likelihood & -150.33 & -120.03 & -120.03 & -120.03 & -120.03 & -120.03 \\
\hline
\end{tabular}

1171 Note: Number of obs. 272 researchers. ${ }^{* * *},{ }^{* *}$ and $*$ Significance at the $1 \%, 5 \%$ and $10 \%$ levels, respectively. 
1174 Appendix B1: List of interviewees included in this study

\begin{tabular}{|c|c|c|c|c|c|c|c|c|c|c|}
\hline 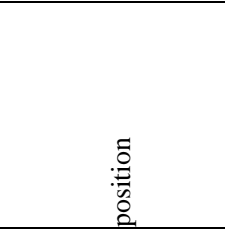 & 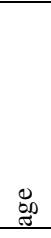 & 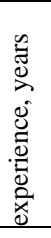 & 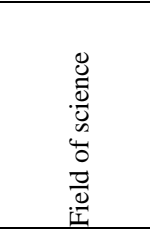 & 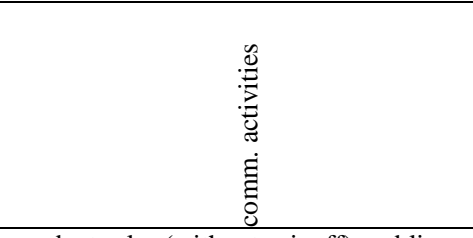 & 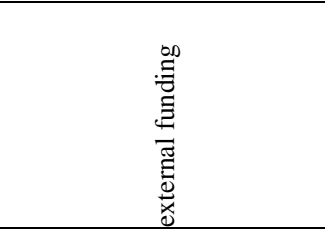 & 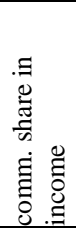 & 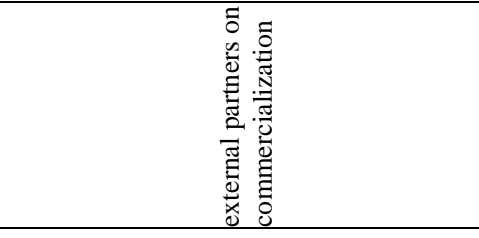 & 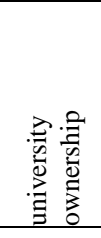 & $\begin{array}{l}\text { : } \\
\text { 吾 } \\
\end{array}$ & 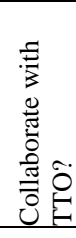 \\
\hline associate professor & 64 & 10 & engineering & $\begin{array}{l}\text { product sales (without spinoff), public } \\
\text { grants, consulting, honorarium }\end{array}$ & private industry capital & 60 & industry & public & BY & No \\
\hline assistant professor & 27 & 1 & social & public grants, honorarium & foreign grants, university & 30 & $\begin{array}{l}\text { other academic institutions, foreign } \\
\text { institutions, other for profit and non-for- } \\
\text { profit }\end{array}$ & public & BY & No \\
\hline research fellow & 31 & 8 & economics & $\begin{array}{l}\text { establishing a spin-off, } \\
\text { product sales (without spinoff), public } \\
\text { grants }\end{array}$ & $\begin{array}{l}\text { government grants, foreign } \\
\text { grants, private industry } \\
\text { capital }\end{array}$ & 80 & $\begin{array}{l}\text { other academic institutions, foreign and } \\
\text { public institutions, industry, profit and } \\
\text { non-for-profit }\end{array}$ & private & BY & Yes \\
\hline research fellow & 60 & 39 & chemistry & $\begin{array}{l}\text { licencing patents, public grants, } \\
\text { consulting, honorarium }\end{array}$ & government grants & 2.6 & $\begin{array}{l}\text { other academic institutions, foreign } \\
\text { institutions, industry, other for profit and } \\
\text { non-for-profit }\end{array}$ & public & BY & Yes \\
\hline full professor & 66 & 47 & economics & $\begin{array}{l}\text { product sales (without spinoff), } \\
\text { public grants, honorarium }\end{array}$ & foreign grants, university & 10 & $\begin{array}{l}\text { other academic institutions, foreign } \\
\text { institutions, industry }\end{array}$ & public & BY & Yes \\
\hline full professor & 60 & 35 & economics & $\begin{array}{l}\text { product sales (without spinoff), public } \\
\text { grants, consulting, honorarium }\end{array}$ & foreign grants, university & 10 & foreign institutions, industry & public & BY & Yes \\
\hline associate professor & 37 & 15 & economics & public grants, honorarium & $\begin{array}{l}\text { government grants, } \\
\text { university, self }\end{array}$ & 5 & $\begin{array}{l}\text { other academic institutions, foreign } \\
\text { institutions }\end{array}$ & public & BY & No \\
\hline associate professor & 33 & 6 & social & honorarium & university, self & 2 & foreign institutions & public & BY & No \\
\hline assistant professor & 35 & 8 & social & consulting & university & 1 & $\begin{array}{l}\text { public institutions, industry, other for } \\
\text { profit and non-for-profit }\end{array}$ & public & BY & Yes \\
\hline associate professor & 51 & 27 & engineering & licencing patents & private industry capital & 25 & foreign institutions & public & KZ & Yes \\
\hline full professor & 57 & 32 & engineering & public grants & government grants & 30 & other academic institutions & public & $\mathrm{KZ}$ & No \\
\hline full professor & 57 & 36 & biosciences & honorarium & university & 80 & Private Industry & public & $\mathrm{KZ}$ & No \\
\hline assistant professor & 26 & 4 & economics & public grants & government grants & 15 & foreign institutions & private & $\mathrm{KZ}$ & No \\
\hline full professor & 64 & 40 & food & multiple & government grants & 10 & Private industry & private & $\mathrm{KZ}$ & Yes \\
\hline full professor & 56 & 27 & economics & $\begin{array}{l}\text { product sales (without spinoff), public } \\
\text { grants, consulting }\end{array}$ & government grants, self & 10 & public institutions, industry & private & $\mathrm{KZ}$ & No \\
\hline full professor & 50 & 20 & law & public grants, honorarium & $\begin{array}{l}\text { government grants, } \\
\text { university, self }\end{array}$ & 10 & other academic institutions & private & $\mathrm{KZ}$ & No \\
\hline full professor & 47 & 27 & $\begin{array}{l}\text { physics \& } \\
\text { math }\end{array}$ & $\begin{array}{l}\text { licencing patents, public grants, } \\
\text { honorarium }\end{array}$ & $\begin{array}{l}\text { foreign grants, university, } \\
\text { self }\end{array}$ & 1 & $\begin{array}{l}\text { other academic institutions, foreign } \\
\text { institutions, industry and professional } \\
\text { associations, for profit and non-for-profit }\end{array}$ & private & $\mathrm{KZ}$ & No \\
\hline full professor & 61 & 37 & economics & public grants, honorarium & $\begin{array}{l}\text { government grants, } \\
\text { university, self }\end{array}$ & 30 & other academic institutions & private & $\mathrm{KZ}$ & Yes \\
\hline full professor & 60 & 36 & medicine & $\begin{array}{l}\text { establishing a spin-off, product sales } \\
\text { (without spinoff), public grants, } \\
\text { honorarium }\end{array}$ & $\begin{array}{l}\text { government grants, foreign } \\
\text { grants }\end{array}$ & 30 & $\begin{array}{l}\text { other academic institutions, foreign and } \\
\text { public institutions, other for profit and } \\
\text { non-for-profit }\end{array}$ & private & $\mathrm{KZ}$ & No \\
\hline assistant professor & 40 & 5 & engineering & $\begin{array}{l}\text { licencing patents, product sales (without } \\
\text { spinoff), public grants }\end{array}$ & $\begin{array}{l}\text { private industry capital, } \\
\text { university }\end{array}$ & 30 & Private industry & private & $\mathrm{KZ}$ & No \\
\hline
\end{tabular}




\begin{tabular}{|c|c|c|c|c|c|c|c|c|c|c|}
\hline full professor & 69 & 35 & $\begin{array}{l}\text { chemistry, } \\
\text { medicine }\end{array}$ & public grants, honorarium & $\begin{array}{l}\text { government grants, foreign } \\
\text { grants }\end{array}$ & 50 & $\begin{array}{l}\text { other academic institutions, foreign } \\
\text { institutions }\end{array}$ & public & $\mathrm{KZ}$ & No \\
\hline associate professor & 35 & 10 & medicine & public grants, honorarium & government grants, self & 3 & $\begin{array}{l}\text { other academic institutions, foreign } \\
\text { institutions }\end{array}$ & public & $\mathrm{KZ}$ & Yes \\
\hline full professor & 50 & 27 & biosciences & establishing a spin-off, public grants & government grants & 10 & other for profit and non-for-profit & private & $\mathrm{KZ}$ & No \\
\hline research fellow & 37 & 15 & $\begin{array}{l}\text { engineering, } \\
\text { physics \& } \\
\text { math }\end{array}$ & $\begin{array}{l}\text { establishing a spin-off, product sales } \\
\text { (without spinoff), } \\
\text { public grants, consulting }\end{array}$ & $\begin{array}{l}\text { government grants, private } \\
\text { industry capital, university }\end{array}$ & 25 & $\begin{array}{l}\text { other academic institutions, public } \\
\text { institutions, , industry, other for profit and } \\
\text { non-for-profit }\end{array}$ & public & $\mathrm{AZ}$ & Yes \\
\hline associate professor & 36 & 10 & economics & public grants, consulting & $\begin{array}{l}\text { foreign grants, private } \\
\text { industry capital }\end{array}$ & 40 & $\begin{array}{l}\text { foreign institutions, industry and } \\
\text { professional associations }\end{array}$ & public & $\mathrm{AZ}$ & No \\
\hline associate professor & 42 & 20 & economics & $\begin{array}{l}\text { establishing a spin-off, product sales } \\
\text { (without spinoff), public grants, } \\
\text { consulting, honorarium }\end{array}$ & $\begin{array}{l}\text { foreign grants, private } \\
\text { industry capital, affiliated } \\
\text { university, self }\end{array}$ & 20 & $\begin{array}{l}\text { other academic institutions, industry and } \\
\text { professional associations, industry, other } \\
\text { for profit and non-for-profit }\end{array}$ & private & $\mathrm{AZ}$ & Yes \\
\hline research fellow & 33 & 6 & social & $\begin{array}{l}\text { licencing patents, establishing a spin-off, } \\
\text { product sales (without spinoff), public } \\
\text { grants, consulting }\end{array}$ & $\begin{array}{l}\text { foreign grants, private } \\
\text { industry capital }\end{array}$ & 5 & foreign institutions & private & $\mathrm{AZ}$ & Yes \\
\hline
\end{tabular}

Note: Interviewee names are not disclosed.

industry capital

Source: Academic entrepreneurship in Belarus (BY), Kazakhstan (KZ) and Azerbaijan (AZ) project interviews 


\section{Background and Overview of the researcher}

Please note, before the interview, the interviewer may be able to gather much of the data for this section from the participating respondent. In fact, it is strongly recommended collecting this data as soon as possible, as these data are important for drawing inference across field of research, type of commercialization, partner in research commercialization and respondent's individual characteristics.

\section{Eligibility criteria to participate in this interview. Please confirm:}

1. You commercialise knowledge and technology created at the university (Yes/No).

2. You are actively involved in any of the research commercialization activity (e.g. establishing a spin-off, product sales (without spinoff), public grants, consulting, honorarium) with a share of commercialization in total income greater than zero (Yes/No).

3. Your research is sponsored by at least one external collaboration partner (e.g. university, government, foreign, private industry in addition to self-sponsorship if any) (Yes/No). Interview questions

- What is your name? What is your position at university?

- How many works have published over the last 5 years, including industry publications with practitioners?

- What is your field of research? What is a secondary or complementary field of research?

- Do you know if any of your academic colleagues commercialize their research?

- Can you say that your university and country business environment is friendly towards the idea of academic entrepreneurship?

- Do you feel an increase of research to teaching ratio would increase your commercialisation capacity and income and why?

- What barriers do you face in commercializing your research from the department/ faculty level, from university level, from business environment?

- What is the most substantial source of commercialization of your research from the following licensing of the patents, running spin-off company, selling products without starting spinoff, getting grants, consulting activity, getting honorarium for books, conferences, lections other?

- In case of positive commercialization we ask: How do you protect your IP?

In case of no commercialization we ask: If you were to start an own business to commercialize your research what are the factors which prevent you from this: financial (economies of scale, taxes) ; administrative and institutional (corruption, doing business conditions), external support or no support (venture and angel investors, crowdfunding, etc.)

- What do you think should be done to enable researchers establish own business (Spinoffs)?

- Please name one or two preferred external partners in commercialization of your research?

- How often do you collaborate with Technology transfer offices (TTO) at your university?

- What are the major challenges you experience when collaboration with TTO?

- What could be improved in the work of TTO to make them more effective?

- $\quad$ Should TTO be a middleman (entrepreneur) between you and a company interested in your research? Who is there instead of TTO to help you linking to business (techno parks, incubators, business networks, professional association, etc.)?

- $\quad$ Please list one or two most important external sponsors for your research

- $\quad$ Would you like to name few recommendations, which in your opinion, could be quickly implemented by policy-makers and university administration?

We thank you for your time and collaboration. 